Article

\title{
Public Participation and Information Disclosure for Environmental Sustainability of 2022 Winter Olympics
}

\author{
Guizhen $\mathrm{He}^{1,2, *}$, Gulijiazi Yeerkenbieke ${ }^{1,2}$ and Yvette Baninla ${ }^{1}$ \\ 1 State Key Laboratory of Urban and Regional Ecology, Research Centre for Eco-Environmental Sciences, \\ Chinese Academy of Sciences, Beijing 100085, China; gulijiazi2018@163.com (G.Y.); \\ baninla2005@yahoo.com (Y.B.) \\ 2 College of Resources and Environment, University of Chinese Academy of Sciences, Beijing 100149, China \\ * Correspondence: gzhe@rcees.ac.cn; Tel.: +86-10-6284-4160
}

Received: 28 July 2020; Accepted: 16 September 2020; Published: 18 September 2020

\begin{abstract}
As China prepares to host the 2022 Winter Olympics, the Beijing Winter Olympics Organizing Committee has committed to making public participation a fundamental part of its broader sustainability objectives. Unfortunately, the existing research on information openness and public participation towards Winter Olympic Games is limited in the perspective of host residents. Therefore, this article aims to understand the information disclosure and public participation, as well as the roles information and technologies (ICTs) play in achieving environmental sustainability. With the help of self-administered questionnaires, data were compiled. The survey was conducted in April 2017 with 650 residents in Beijing and Zhangjiakou via face-to-face interviews to obtain a random and statistically representative sample of host residents. Our findings indicated that only few respondents participated in the limited activities of Beijing 2022 Winter Olympics. The respondents' views on important issues of public participation varied obviously including the participating level, principles, time, ways, mechanism, and influencing factor. The analysis illustrated over $70 \%$ of respondents had the positive attitudes towards ICTs roles and functions in Beijing 2022. ICTs have helped the public to obtain information about environmental management and sustainability issues, and to facilitate public awareness and collective action by building new management practices. This study has implications and contributes to the burgeoning literature surrounding the Olympic Games by providing an in-depth analysis of public participation in relation to the theory.
\end{abstract}

Keywords: Winter Olympic Games; public participation; questionnaire survey; resident opinion; China

\section{Introduction}

The Winter Olympic Games were meant to become a game changer for the host city's road to big push modernization [1,2]. During recent years, the Olympic Games have increasingly been used by host nations to manifest their own green visions and sustainability strategy [3,4]. In the mid-1990s, the International Olympic Committee (IOC) adopted a new clause on environmental protection and sustainable development for the Olympic Games within the Olympic Charter [5]. The turning point came with the development and launch of Olympic Agenda 2020, the strategic roadmap for the future of the Olympic Movement, which was approved at the 127th IOC Session in December 2014 [6]. Sustainability, together with credibility and youth, is one of the three pillars of Olympic Agenda 2020. In 2015, a specific Sustainability Strategy arose directly from Olympic Agenda 2020 and was approved in December 2016 [7]. It was also developed in the context of a landmark global initiative: The United Nations (UN)'s 2030 Agenda for Sustainable Development, which came into force on 1 January 2016. Sustainability is now fully embedded throughout the entire lifecycle of the Olympic Games, from the 
candidature to the planning and the delivery of the Games, and through to their legacy. The Olympics was highlighted as an "important enabler" to achieve the ambitious agenda of the UN Sustainable Development Goals (SDGs).

In 2015, Beijing-Zhangiiakou was elected to host the 2022 Winter Olympic (hereafter Beijing 2022), making history as a city that hosts both Summer Olympic Games and Winter Olympic Games. As the first Games to put Olympic Agenda 2020 into practice from the very beginning of the bidding process, Beijing 2022 will follow the IOC guidance to set up Beijing's standards in sustainability. On 16 November 2018, the Inauguration Ceremony and the 1st Plenary Session of Beijing 2022 Sustainability Advisory Commission was held at the Beijing 2022 Headquarters. Beijing 2022's sustainability drive includes the following six aspects: fulfill Beijing 2022's sustainability commitment, establish a sustainability management system, ensure sustainable management of venues, implement sustainable sourcing, accelerate low-carbon development, and strengthen communications and public participation. The government of China was firmly committed to staging the games with a green, inclusive, and open approach. Beijing and Zhangjiakou are promoting the smart city to help the successful hosting of the Beijing 2022 [8].

Public participation, or stakeholder participation, is the process where stakeholders are involved and included in decision-making processes so that their concerns, needs, and values are taken into consideration in the result [9]. Public participation is not only the implementation of the concept of "Sharing Olympic Games", but also the solemn promise of the Bid Report and the need for sustainable development of Olympic sports. Beijing Winter Olympics Organizing Committee (BWOOC) is the core of the public participation plan and carried out a series of activities throughout China. It generally includes Olympic culture and education, plan of public participation in winter sports, sustainability and Olympic legacy planning, brand promotion of Beijing Winter Olympic Games, volunteer and related services, Winter Olympic torch relay, ticketing and Winter Olympic spectators. To ensure sustainability, Beijing 2022 will widely adopt public opinions and consider the interests of all relevant parties, so as to deliver the Olympic Winter Games in a more inclusive manner, and achieve the harmony of the city's vision, the nation's will, and public expectation [10]. Through public engagement, organizations can be expected to understand and elucidate the different dimensions of the environmental challenge they face.

On the waves of information and communication technologies (ICTs) and globalization processes, a new informational mode of environmental governance is emerging. In particular, internet and mobile phone-based social media, which includes amongst others blogs, messaging services, wikis, micro-blogs, social networking platforms such as Facebook, was used for effective communication in urban sustainability and environmental accidents [11,12]. Unlike traditional media, it allows for multidirectional and multilevel communication. To make public institutions more inclusive, effective, accountable, and transparent, as called for in the 2030 Agenda for Sustainable Development, many governments across the globe are opening their data to the public.

Large-scale events such as the Olympics have been recognized for their role in highlighting the international profile of the host country or region. Scholars advocated the resident perception study as an integral part of the mega-event cost-benefit analysis. Extensive research has been conducted on host and non-host resident perceptions of mega events and particular Olympics, but most of the attention is focused on cities and regions in Western countries such as London, Calgary, Vancouver, and Salt Lake City [13-18]. Deccio and Baloglu (2002) examined non-host community residents' perceptions of the spillover effects of the 2002 Winter Olympic Games, the antecedents of these perceived impacts, and consequent support for the Olympics. Results showed that although some residents perceived that the Olympics would bring opportunities, most did not anticipate any local impact from the event. Findings indicate that environmentally conscious residents do not support the Olympics [19]. The Olympics outside of the Western world have often escaped academic attention. In the case of the Olympic Games, for example, comparatively little is known about the games in Beijing 2008 [20]. Resistance may occur if people feel that they are excluded from decision making and perceive the decision-making procedures as unfair. The third pillar of the Aarhus Convention regarding 
public participation has been addressed by the United Nations and implemented by the European Directive 2003/55/EC with the purpose of strengthening the provisions for public participation in EIA [21]. However, little, if any, research exists that focuses on information openness and public participation towards Winter Olympic Games, especially examined perceptions and attitudes of host community residents towards it. Such knowledge is critical to inform decision-makers that regulate public participation procedures. As a contribution towards understanding the picture of information disclosure and public participation, the present paper examines the host resident's perception and engagement of the preparation for the 2022 Winter Olympic Games in Beijing and Zhangjiakou. Public participation has been flagged as a key factor for socially acceptable environmental policies and projects [22-24]. Public participation refers here to processes organized by responsible parties (e.g., government agencies, other public- or private-sector organizations, and the public) to deliberately engage the public in the planning, development, and implementation of Beijing 2022 [9]. In the background of e-government and smart cities, the objective of this study is to understand both information openness and host-resident participation. Specifically, the roles that ICTs can play in promoting information disclosure and public participation in achieving environmental sustainability of the Beijing 2022 Winter Olympics. This article aims to understand the information disclosure and public participation, as well as ICTs' roles played in achieving environmental sustainability in Beijing 2022. Focusing on the preparation stage, a questionnaire survey was conducted from February to April 2017. We investigated 614 host residents of two districts in Beijing and one district in Zhangjiakou, located within proximity $(100 \mathrm{~km})$ to an upcoming 2022 Winter Olympics in Beijing-Zhangjiakou. The results provide initial evidence that local people especially want to participate in Beijing 2022. This gives impetus for a novel approach to examine whether and how the whole decision-making chain could be reconfigured to provide more room for public influence. The study contributes to the burgeoning literature surrounding the Olympic Games by providing an in-depth analysis of public participation in the preparation stage. This paper begins by introducing the literature review in terms of public participation and ICTs application in Section 2. The survey and data are presented in Section 3. Next, we report findings from content analysis and statistical analysis about residents' perceptions related to participation, information openness, and ICTs roles in the Beijing 2022 Winter Olympics. Finally, we discuss the results before summarizing implications and suggesting future research.

\section{Environmental Public Participation and ICTs Application}

\subsection{Environmental Public Participation}

Legal frameworks, such as the Aarhus Convention, mandate extensive obligations to engage the public in decision making on local projects. Public participation is defined as "a generic term for all types of activities designed to include the public in the decision-making process, prior to and after a decision" [25]. Carpenter and Brownill (2008) observed that there is a strong link between strategies of participation and approaches to democracy. In terms of models of governance, four models were widely used to describe Western governance systems: representative democracy, pluralist democracy, corporativism, and clientelism [26]. Another form of democracy is a more participatory one called deliberative democracy [27]. At its heart is the Communicative Theory of Habermas, which means deliberative democracy emphasizes agreement between a range of stakeholders through negotiation by using communicative rationality $[26,27]$. There are clear similarities between the ideal of deliberative democracy (including its approach to public participation) and the current strand of planning theory: collaborative planning [28]. Supported by this approach is the view of participation as an opportunity to engage and involve the public in the decision-making process proactively. This differs from the notion of public participation built on the approach of representative democracy which is characterized by minimum engagement with the public as elected politicians are entitled to make decisions in the name of citizens who elected them [26]. Furthermore, the adoption of more collaborative forms 
reflects the deliberative ideal in relation to environmental democracy and sustainability in line with the principles of the Agenda 21.

Public participation "is inclusive and open, involves multiple perspectives and forms of knowledge, is jointly undertaken by stakeholders, and it is directed toward and guided by substantive environmental management, environmental justice, and sustainability ends" [25]. As proposed in prior studies, the Olympic Games may also directly influence sport participation by inducing attitudinal changes toward sport. The finding of Aizawa et al. (2018) [29], along with the empirical evidence showing that cohort affects sport participation, suggests that membership in a specific cohort may mediate the effect of the Olympic Games on individuals' attitudes and behavior toward sport participation. Public participation is a vital practice for cost-efficient environmental decision-making, whose gains include keeping social conflict at bay, acquiring legitimacy for the decisions made, and better environmental outcomes [30,31]. Public participation plays a key role in the sense that it can foster social learning between stakeholders by identifying four components (public involvement, communications, mutual education, and negotiations) [25]. The commonly proposed benefits of public participation include its (1) normative function, namely democratizing the decision-making process, (2) substantive function, namely enabling the public to understand scientific facts and to advance decision making by bringing in their own knowledge, values, and concerns, and (3) instrumental function, namely increasing the legitimacy and social acceptability of the decision-making procedures and their outcomes [32-34].

Some relevant models of participation in environmental management are proposed. The participation model of Cashmore (2004) places stakeholder involvement at the center of the scientific model, which means stakeholders have a more substantial, inclusive and deliberative role with this model [35]. This participation model has strong links with his environmental governance model which aims to empower stakeholders in order to achieve more sustainable forms of development. The pluralist politics model of Bartlett and Kurian (1999) aims to achieve a higher degree of public participation in the decision-making process [36]. Richardson (2005) points that participation is being considered more in relation to a procedural issue rather than a value one from a planning perspective. In line with this model, participation is necessary because there is a need to convert decision making in the environmental field into a more responsive and transparent process, "democratizing democracy, if not deliberative democracy"; and to embrace the multitude and plurality of values and priorities within society [37]. Both models of participation plus the environmental governance model of Cashmore are strongly associated with the approaches of deliberative democracy and collaborative planning, all of which have communicative rationality at the heart.

Public participation is a two-way communication and interactive process where information and viewpoints are exchanged between stakeholders and formal decision-makers. The goal of participation is to achieve a transparent, balanced, and widely supported decision through greater input from stakeholders. Webler et al. identified five discourses, or perspectives, about a good process of public participation, which include popular legitimacy, an ideological discussion, the fairness of the process, a power struggle, and the need for leadership and compromise [38]. Participation can take various forms ranging from public meetings and hearings, questionnaire surveys, focus groups, notice and comment procedures, advisory committees to more complex deliberative processes with the ultimate goal of enabling the participants to have greater insight into decision-making procedures leading to more informed opinions on environmental issues, as well as those considered more innovative-such as regulatory negotiations, mediations, and citizen juries. In terms of major sports events and related infrastructure, it is a valuable opportunity for the public and key stakeholders to show their views, learn more about the project and engage with the event. For a project of the scale of the Olympic Games, it is important to highlight that there are several stakeholders such as statutory bodies, local authorities, local interest groups, and pressure groups, among others to be consulted and engaged in the planning process [39]. It demonstrated that public participation within the environmental impact assessment 
process informed the decision-making and planning process for London 2012 and for the Pan American Village of the Rio 2007 Games.

\subsection{E-Participation and ICTs Application}

The advent of ICTs allows for different institutions and individuals to gather information, hold consultations, vote online, and as such express their opinions. E-Government is digital interactions between a government and citizens (G2C), government and businesses (G2B), government and employees (G2E), and also between government and governments or agencies (G2G) [40]. E-Government should enable people to visit state websites to communicate and interact with employees through the internet, instant messaging, email, and audio or video presentations and is becoming popular in developing as well as in developed countries. Opening data can be an essential measure to increase transparency and accountability, promote participation, and stimulate innovation in institutions. With growing access to new media, an increasing number of countries and organizations now proactively use networking opportunities to engage with people and evolve towards participatory decision-making [41]. Open government data refers to "government information proactively disclosed and made available online for everyone's access, reuse and redistribution without restriction" [42]. This is done through open data, online consultations, and multiple ICT-related channels [43-45]. Making data available online for free also allows the public - and various civil society organizations- to reuse and remix them for any purpose. Access to public information is a vital first step in promoting people's empowerment and citizen engagement in public policy decision-making processes [46]. Open government and organization data help promote effective participation in decision-making processes, reduce waste of resources, and unleash opportunities for innovation and economic growth [8,47].

It is clear that the widespread use of the internet has opened up great possibilities for social and political participation that were not possible before. The internet has facilitated the emergence of a new communication system. The advantages of the internet for participation can be summarized in four main points: (1) it makes it easier and faster for people to get information on public issues; (2) it also facilitates the engagement in political participation by reducing the cost of social pressure: an individual can privately sign a petition on a controversial issue from their computer at home; (3) individuals can themselves encourage the participation of others through online platforms or by disseminating information through their social networks; (4) furthermore, the internet facilitates activism at the global scale and complements today's social repertoire of collective action [48].

E-participation is defined "as the process of engaging citizens through ICTs in policy, decision-making, and service design and delivery in order to make it participatory, inclusive, and deliberative" [42]. Using ICTs, e-participation is a tool that promotes the inclusion of the public in participative and deliberative decision-making processes, thus contributing to a transformation of the interaction between government and citizens in environmental governance and sustainable development [11]. Medaglia (2011) indicates that the field has a high level of dynamism, as focuses on eParticipation activities, contextual factors and effects have shifted in time, sometimes in counterintuitive directions [49]. In general, eParticipation actors include citizens, politicians, government institutions, and voluntary organizations. The common eParticipation activities are eVoting, online political discourse, online decision making, eActivism, eConsultation, eCampaigning, and ePetitioning. eParticipation effects cover civic engagements effects, deliberative effects, and democratic effects. The usually mentioned contextual factors consist of information availability, infrastructure, underlying technologies, accessibility, policy and legal issues, and governmental organization.

More and more studies address the ICT roles, application, and barriers in public participation. Wagner et al. (2016) offer a comprehensive overview of potential developments in the field of public participation that are driven by ICT and social developments [50]. An evaluation of future developments in public decision-making discussed ten projections concerning future public participation and obtained knowledge about expected developments, their desirability and their impact on political actions [51]. Bertot et al. (2012) highlight the opportunities and challenges in implementing ICT in the public 
sector and provide a comprehensive list of key policies and research questions related to the topic [52]. A research field called public participation geographic information systems (PPGIS) has emerged to investigate the use and value of GIS by marginalized peoples and communities engaged in social change [53]. Higgs et al. (2008) focus on integrated approaches that involve the use of Geographical Information Systems (GIS) and Multi-Criteria Decision Analysis (MCDA) techniques in facilitating public participation using the case study of the planning of wind farms [46]. Mukhtarov et al. (2018) point out that ICT tools allow many citizens to be better informed and co-produce water services with a government by analyzing 32 case studies. The different types of ICT enabled interactions in urban water governance practice include (1) citizen sourcing: providing governments with necessary information (C2G), (2) government as a platform: informing, educating, and nudging citizens (G2C), (3) "do-it-yourself" government: exchanging information among citizens and community initiatives (C2C), and (4) collaborative planning and groupware: government-citizen coproduction (GwC) [54]. Social media and internet-based participation tools are also discussed by some scholars in $[55,56]$. In addition, the local media tends to provide substantial coverage of the latest progress for a sport event, which would greatly raise local residents' awareness of the event [57]. Ristea et al. (2018) use tweets to understand changes in the spatial crime distribution for hockey events in Vancouver [58].

China is of course not an average country when we consider environmental information disclosure and informational governance. The mandatory environmental information disclosure has been increasingly inserted in many national laws, such as those on environmental impact assessment, air pollution prevention and control, and water pollution prevention [59]. Environmental information disclosure, however, was considered a one-way dissemination tool (as intra-departmental or government-to-public information flow), rather than a governance instrument in last century [60]. The main conventional information institutions, such as television, newspapers, the radio and news agencies, have been kept in state hands for a long time. However, over the past decade a significant change has taken place regarding the state's monopoly in information and informational processes. Moreover, the environmental field is leading in a cautious move to bounded information pluralism and transparency $[61,62]$. Our study illustrates that in the information disclosure process the actual functional pathways to achieve improved transparency and environmental effects depend on the information characteristics and which information suppliers and users are involved in the process, including societal actors [59]. Regarding the ICT tools, they are used in emergent events, the Winter Olympics planning, venues project, etc. [63-65]. However, little is known about its roles and application in the public participation. This study aims to fill this gap.

\section{Research Framework and Methods}

\subsection{Research Framework and Questions}

According to empirical studies from Western countries, a range of theories and concepts have been developed over the last fifty years to explain how and why individuals and communities participate in collective action, such as crowd behavior theory, collective action theory and "free-riding" behavior, resource mobilization theory, political process theory, new social movement theory, political opportunity (structure), and social contagion theory [22]. Social exchange theory, a theory of social interaction, has been utilized as an appropriate and effective foundation to study residents' perceptions based on awareness, attitude, and intention [66]. Research indicates this theory may explain residents' motivations for entering into an exchange or lack of support for such an exchange [19]. The social ecological model's central tenet is that multilevel interventions from internal variables, such as demographic and psychological variables, and external variables, such as political and social variables, can influence people's behavior [29]. Not all of these frameworks are equally useful and relevant for understanding public attitude and participation in environmental affairs of the Winter Olympics in contemporary China. From the emerging literature on Beijing 2008 Summer Olympics, we learn that the social exchange theory was applied [20]. 
Compared to Western countries, in China, public participation in environmental decision-making is organized differently, the rules and resources by individual and collective actions differ. Referring the social ecological model and social exchange theory, we developed a research framework used in this study (Figure 1). This framework identifies the environmental sustainability of Winter Olympic Games as a key topic attracting people's concerns and participation. Beijing 2022 consists of four periods: (a) the bidding process, (b) the preparation stage, (c) event hosting, and (d) the post-event stage. Here, we focus on the preparation stage. Different stakeholders, such as government, company, non-governmental organizations (NGOs), and the public, have proactively attended or piloted to address existing environmental regulatory inadequacies. Our framework depicts only the hypothesized relationships among residents' demographic characters and their perceptions, publication, information sources, ICT application for the Olympics.

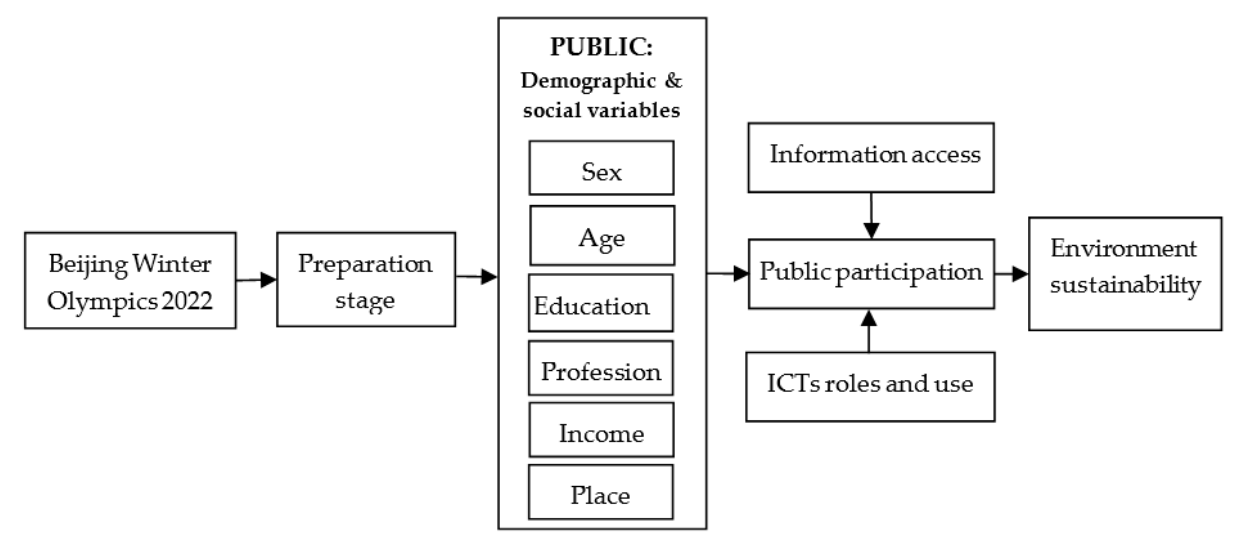

Figure 1. The framework of this research.

From a practical perspective, the article seeks answers to the following questions: (1) Do host residents participate in and what are their attitudes towards the environmental public participation of the 2022 Winter Olympics? (2) What are the main information sources and roles of the ICTs played in the environmental management and sustainability of Beijing 2022? (3) Which are main factors affecting the host residents' attitude and knowledge of public participation? We will show the results in Section 4.

\subsection{Data Collection}

This study is a quantitative study in general. We mainly collected data by face-to-face questionnaire surveys with the same questionnaire from February to April 2017. The structured (numerical) data could be plugged into a spreadsheet and analyzed with statistical methods later. The official documents review and government websites were used for related information collection and reference for questionnaire design. The first author drafted a questionnaire according to our goal and defined the required information. The fixed-alternative type is used by providing multiple-choice answers. The questions are designed for dichotomous and multichotomous responses (see Supplementary Materials). Some questions used a Likert scale. Likert scales (named after their creator, American social scientist Rensis Likert) are quite popular because they are one of the most reliable ways to measure opinions, perceptions, and behaviors. The question uses a 5-point scale, sometimes referred to as a satisfaction scale, which ranges from one extreme attitude to another. For ranking of ICT tools and functions, the respondents were invited to evaluate them. If one ICT and a function were ranked the No.1, it would get 10 points or 8 points. The last ones would get 1 point. The ranking of each role is calculated by total points (multiplying the number of respondents by the points).

The draft questionnaire was pre-tested in two stages by face-to-face interviews with five experts and 12 residents in February and March 2017. In the first stage, it was administered using personal interviews with five experts, who are researchers from one institute and one university in Beijing and 
have masters and PhD degrees in the major of environmental science and/or ecology. We got better feedback on problems such as ambiguous questions, the questionnaire structure, contents, and page layout. In the second stage, the questionnaire was tested in the same way it will be administered. The sampled 12 residents were randomly chosen from two communities in Beijing. They were invited to fill in the questionnaire and gave some advice on the understandability, clarity, and specific details, etc. The questionnaire was revised twice based on their suggestions. Finally, the questionnaire is divided into three sections: demographics, perception on information disclosure, participation actions and behavior, and perceived functions and impacts of different ICTs for participation in Beijing 2022 Winter Olympics.

The survey area is Beijing and Zhangjiakou-host cities of 2022 Winer Olympic Games. Venues for Beijing 2022 will be located in the three Games Zones of downtown Beijing, Yanqing District and Chongli of Zhangjiakou (Figure 2). About 100,000 residents live around Aoyuncun subdistrict office in Chaoyang District. There were 280,000 residents in Yanqing District and a 104,000 population in Chongli District. In downtown Beijing, 230 households were randomly sampled in two communities around the venues of Beijing 2022. In Yanqing, 210 households were randomly sampled in one town near the venues of Beijing 2022 and downtown. In Chongli, 210 households were randomly sampled in one town near the venues of Beijing 2022 and downtown. The formal face-to-face questionnaire surveys were conducted by the first author and investigators from GR Survey Company in April 2017. Using a face-to-face survey, our study included residents who had no access to the Internet and people interested in the survey and questions. Eight investigators surveyed 650 residents from 1-10 April 2017. All respondents received the same questions. A questionnaire providing complete answers to all questions was regarded qualified. Finally, a total of 614 valid questionnaires were returned (average response rate of $94.3 \%$ ) due to the absence of some socioeconomic background variables. The margin of error (MOE) for the total sample of $n=650$ is \pm 5.7 percentage points. To ensure the data were gathered from a representative group of Beijing and Zhangiiakou, sample quotas were set by age, gender, and city quadrant of the general population aged 18 and older. In the previous surveys, samples changed from hundreds to thousands; for example, Gordon et al. (2014) conduced a mailback questionnaire among 698 residents randomly sampled in three urban communities (Boise, Reno, and Salt Lake City) and three rural communities (counties in Nevada, Oregon, and Utah) in USA [67]. Gaskell et al. (1999) surveyed 16,500 samples (about 1000 respondents per country) in 17 European countries and 1067 samples in the USA about genetically modified foods. The response rate (respondents with a complete set of responses) was $73.8 \%$ (12,178 completed) in Europe and 80.8\% (863 completed) in the USA [68]. Therefore, a sample size in our study is large enough for this kind of public survey.

\subsection{Data Analysis}

Responses were collected in Microsoft Excel. Qualitative and open-ended responses were coded and post-coded to summarize the data. Table 1 shows the social and demographic information of the respondents. There was a little bias in our sample towards certain categories such as gender, age, and education. According to Beijing census data in 2010, the rates of male and female are $51.6 \%$ and $48.4 \%$ respectively. The rate of people with education at primary/middle school, high school, and university and over are $43.1 \%, 22.1 \%$, and $32.8 \%$, respectively. The people who are $15-19,20-29$, $30-39,40-49$, and 50-64 years old are $3.5 \%, 25.2 \%, 20.1 \%, 17.4 \%$, and $16.6 \%$, respectively. According to Zhangiiakou census data in 2010, the rates of male and female are $51.2 \%$ and $48.8 \%$ respectively. The rate of people with education at primary, middle school, high school, and university and over are $29.6 \%, 39.1 \%, 13.5 \%$, and $6.8 \%$, respectively. People who are $0-14,15-64$, and more than 64 years old are $15.9 \%, 73.7 \%$, and $10.3 \%$, respectively. 


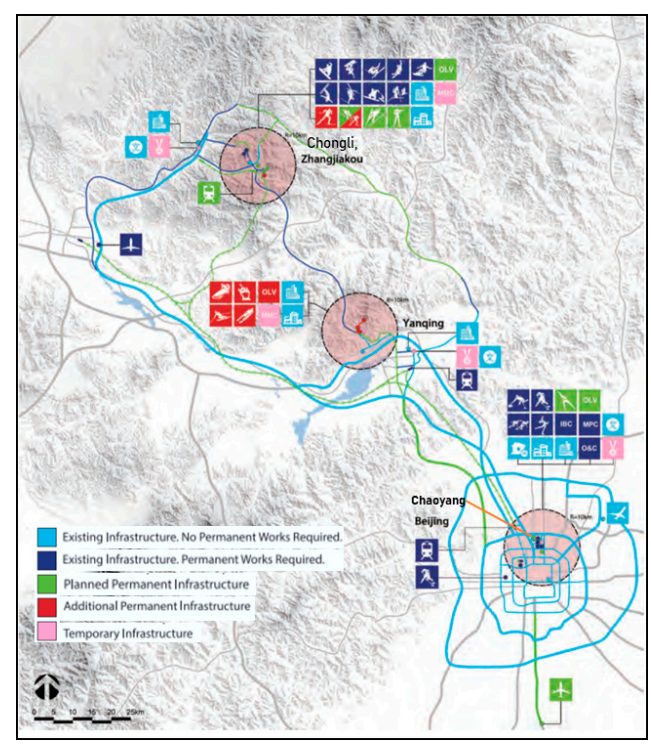

Figure 2. Survey sites of Three Games Zones in Chongli, Yanqing, and Chaoyang Districts.

Table 1. Social and demographic background of the respondents $(n=614)$.

\begin{tabular}{lccllc}
\hline \multicolumn{1}{c}{ Items } & Options & Percent (\%) & \multicolumn{1}{c}{ Items } & \multicolumn{1}{c}{ Options } & Percent (\%) \\
\hline Gender & Male & 46.6 & Profession & Corporate employees & 28.2 \\
& Female & 53.4 & & Farmer & 18.9 \\
Age & $18-30$ & 35.7 & & Self-entrepreneur & 15.5 \\
(years old) & $31-40$ & 19.3 & & Retiree & 11.4 \\
& $41-50$ & 17.6 & & Student & 9.1 \\
& $51-60$ & 14.0 & & Government staff & 7.3 \\
Education & Over 60 & 13.4 & & None or others & 4.6 \\
& Primary school & 8.1 & & Teacher and researcher & 3.4 \\
& Middle school & 28.7 & & Media and NGO staff & 1.6 \\
& High school & 30.0 & Annual & $1-5$ & 53.1 \\
Place of & University & 32.7 & household & $6-10$ & 25.9 \\
residence & Master & 0.5 & income & $11-15$ & 11.2 \\
& City & 54.2 & $(10,000$ RMB) & Over 15 & 9.8 \\
& Rural area & 27.9 & & & \\
\hline
\end{tabular}

Numerical data from the closed-ended questions were analyzed via SPSS version 21.0. Descriptive statistics, Mann-Whitney U test, one-way analysis of variance (ANOVA) and Kruskal-Wallis ANOVA analysis were applied. The quantitative descriptive analysis is used to describe differences among samples such as the amount, percentage, the mean, and standard deviation (SD). Mann-Whitney U statistic, one of nonparametric tests, is used only when the number of observations in each sample is $>20$ and there are 2 independent samples of ranks [69]. Here we used it to compare the differences of participation degree, stratification level, and trust level, etc., between male and female. Analysis of variance (ANOVA) refers to a collection of statistical methods that researchers use to determine whether mean scores differ significantly across treatment groups. One-way ANOVA should only be used with one type of experimental design - a completely randomized design with one factor (also known as a single-factor, independent groups design). The Kruskal-Wallis Test, as a nonparametric test, is used with ranked data, particularly when: (1) the data are ordinal and do not meet the precision of interval data, (2) there are serious concerns about extreme deviation from normal distribution, and (3) there is considerable difference in the number of subjects for each comparative group [70]. Both the Kruskal-Wallis Test and one-way ANOVA are used to determine if there are statistically significant differences for comparisons of three or more groups. In this study, we used ANOVA to analyze how perceptions of and attitudes towards public participation and information disclosure, as well as the roles regarding ICT application, were associated with the respondents' demographic 
variables such as age, education, profession, income, and place of residence. The level of statistical significance was set at $p<0.05$.

\section{Results}

We will describe our results in four subsections. The descriptive statistics are introduced in the first sub-section. Next, we present respondents' personal experiences and attitudes towards environmental public participation. In the third subsection, information transparency, sources, and public trust are showed. Finally, e-participation, ICT roles and ranking in Beijing 2022 environmental public participation are described.

\subsection{Descriptive Statistics}

Table 2 presents the descriptive statistics (mean and standard deviation) for the demographic characteristics of the samples, their participation activities, attitudes, knowledge about Beijing 2022 and ICT roles. Fewer respondents participated in activities of Beijing 2022 (Yes = 1, No = 2; Mean = 1.93, $\mathrm{SD}=0.258$ ). The host residents supported the Beijing-Zhangjiakou joint bid as host for 2022 Winter Olympics (Mean $=4.04, \mathrm{SD}=0.700$ ). The interviewees generally agreed to public participation in the decision-making the Beijing 2022 (from strongly disagree $=1$ to strongly agree $=5$; Mean $=3.49$, $\mathrm{SD}=0.733$ ). Respondents knew partly of the Beijing-Zhangjiakou joint bid for 2022 Winter Olympics (Mean $=3.28, \mathrm{SD}=0.781$ ) but know little (Mean $=2.43, \mathrm{SD}=0.842)$ about the decision-making process of the Beijing 2022 joint bidding. Respondents were largely unaware of the environmental e-participation concept (Yes $=1, \mathrm{No}=2$; Mean $=1.99, \mathrm{SD}=0.379$ ). Regarding the ICTs roles in the environmental public participation of the Beijing 2022, the mean values ranged from 3.86 to 4.09 , while the SD was from 0.663 to 0.818. These results showed that the respondents generally agreed with the positive roles of ICTs.

Table 2. Descriptive statistics of the items and variables.

\begin{tabular}{lcc}
\hline Items and Variables & Mean & Standard Deviation (SD) \\
\hline Sex & 1.53 & 0.499 \\
\hline Age & 4.49 & 2.761 \\
\hline Education level & 2.89 & 0.974 \\
\hline Profession & 4.46 & 2.837 \\
\hline Annual household income & 1.82 & 0.874 \\
\hline Place of residence & 1.64 & 0.768 \\
\hline $\begin{array}{l}\text { Participate in the activities of the 2022 } \\
\text { Winter Olympics }\end{array}$ & 1.93 & 0.258 \\
\hline $\begin{array}{l}\text { Support of Beijing-Zhangjiakou joint bid } \\
\text { and hosting of 2022 Winter Olympics }\end{array}$ & 4.04 & 0.700 \\
\hline $\begin{array}{l}\text { Agree to participate in the } \\
\text { decision making }\end{array}$ & 3.49 & 0.733 \\
\hline $\begin{array}{l}\text { Know about Beijing-Zhangiiakou joint } \\
\text { bid for 2022 Winter Olympics }\end{array}$ & 3.28 & 0.781 \\
\hline $\begin{array}{l}\text { Know about the decision-making process } \\
\text { of joint bidding for Beijing 2022 }\end{array}$ & 2.43 & 0.842 \\
\hline $\begin{array}{l}\text { Know about the environmental } \\
\text { e-participation }\end{array}$ & 1.99 & 0.379 \\
\hline \begin{tabular}{l} 
Roles of ICTs \\
\hline $\begin{array}{l}\text { Getting more information through ICTs } \\
\text { than traditional media }\end{array}$
\end{tabular} & 3.86 & 0.818 \\
\hline $\begin{array}{l}\text { Improving quality of the environmental } \\
\text { information disclosure }\end{array}$ & 3.97 & 0.767 \\
\hline
\end{tabular}


Table 2. Cont

\begin{tabular}{|c|c|c|}
\hline Items and Variables & Mean & Standard Deviation (SD) \\
\hline $\begin{array}{l}\text { Promoting more transparency of } \\
\text { environmental information }\end{array}$ & 3.95 & 0.748 \\
\hline $\begin{array}{l}\text { Providing the information to the public at } \\
\text { any time and anywhere }\end{array}$ & 4.01 & 0.694 \\
\hline $\begin{array}{l}\text { Making it easier for the public to access } \\
\text { environmental information }\end{array}$ & 4.01 & 0.737 \\
\hline $\begin{array}{l}\text { Providing the latest environmental } \\
\text { information to the public }\end{array}$ & 4.03 & 0.725 \\
\hline $\begin{array}{l}\text { Attracting enterprises to invest in } \\
\text { environmental protection }\end{array}$ & 4.00 & 0.762 \\
\hline $\begin{array}{l}\text { Getting public opinions on information } \\
\text { dissemination }\end{array}$ & 4.00 & 0.736 \\
\hline $\begin{array}{l}\text { Improving the environmental } \\
\text { performance of the government }\end{array}$ & 3.98 & 0.738 \\
\hline $\begin{array}{l}\text { Reducing government investment and } \\
\text { cost }\end{array}$ & 3.96 & 0.828 \\
\hline $\begin{array}{l}\text { Increasing public satisfaction with } \\
\text { environmental performance }\end{array}$ & 3.98 & 0.753 \\
\hline $\begin{array}{l}\text { Increasing public trust in environmental } \\
\text { protection }\end{array}$ & 3.97 & 0.736 \\
\hline $\begin{array}{l}\text { Expanding communication channels } \\
\text { between government and public }\end{array}$ & 4.04 & 0.737 \\
\hline $\begin{array}{l}\text { Providing opportunities for public } \\
\text { participation in decision making }\end{array}$ & 4.00 & 0.748 \\
\hline $\begin{array}{l}\text { Providing chances for public participation } \\
\text { without interference in the } \\
\text { decision making }\end{array}$ & 3.94 & 0.794 \\
\hline $\begin{array}{l}\text { Providing e-services regarding the } \\
\text { environment for all people in urban and } \\
\text { rural areas }\end{array}$ & 3.93 & 0.764 \\
\hline $\begin{array}{l}\text { Providing e-services regarding the } \\
\text { environment for all people at any age and } \\
\text { of any gender }\end{array}$ & 3.95 & 0.789 \\
\hline $\begin{array}{l}\text { Providing e-services regarding the } \\
\text { environment for people with specific } \\
\text { demand }\end{array}$ & 4.00 & 0.724 \\
\hline $\begin{array}{l}\text { Providing a space for public, } \\
\text { governments, companies, and NGOs to } \\
\text { communicate }\end{array}$ & 4.07 & 0.696 \\
\hline $\begin{array}{l}\text { Compared with the } 2008 \text { Beijing Summer } \\
\text { Olympics, I think more and more people } \\
\text { are participating in the dissemination of } \\
\text { environmental information of the } 2022 \\
\text { Winter Olympics through the internet }\end{array}$ & 4.05 & 0.673 \\
\hline $\begin{array}{l}\text { I am optimistic about the role of ICTs in } \\
\text { promoting public environmental } \\
\text { participation in the } 2022 \text { Winter Olympics }\end{array}$ & 4.09 & 0.663 \\
\hline $\begin{array}{l}\text { The national information strategy and } \\
\text { policy have a great impact on public } \\
\text { participation in environmentally } \\
\text { sustainable development }\end{array}$ & 4.04 & 0.762 \\
\hline
\end{tabular}

\subsection{Personal Experiences and Attitudes towards Public Participation}

Beijing 2022 needs public support and participation. The degree of people's participation in the preparation process and activities is an important factor influencing the support of them. If people feel 
left out of an event and are presented with projects as faits accomplis that cannot be altered, support is likely to be dampened [18]. After all, it is the residents who will have to live with the results of the decisions. However, only $7.2 \%$ of respondents participated in the activities of the 2022 Winter Olympics in our survey. The mean and standard deviation of the respondents' participation action were 1.93 and 0.258. Mann-Whitney $U$ test showed that there was no significant difference of the participation between male and female participants. Kruskal-Wallis ANOVA analysis indicated that the respondents' demographic characteristics such as age and place of residence had no significant correlation with the respondents' participation in Beijing 2022. There were significant differences between the respondents' participation and their education level $(p=0.029<0.05)$, profession $(p=0.026<0.05)$, and annual household income $(p=0.016<0.05)$. In terms of the sample-sample comparison, there was significant difference of the participation between respondents with annual household income of more than 150 thousand RMB and the other three groups with annual household income $10-50,60-100$, and $110-150$ thousand $\operatorname{RMB}(p=0.000<0.05)$. As for the activities of participation, 59 respondents were directly involved in 13 activities in the past two years. Of them, $24.7 \%$ were involved in visiting the venues for the Winter Olympic Games, followed by a questionnaire survey on environmental impact assessment of the venue project (12.4\%) and public hearing of the Winter Olympics bidding report and venue planning (12.4\%). The least mentioned activity was a symposium and expert seminar on Winter Olympics Bidding and stadium construction (1.1\%). The Beijing Organizing Committee for the 2022 Olympic and Paralympic Winter Games created in December 2015 is a public institution responsible for the organization and coordination of all the preparations and delivery of the 2022 Olympic and Paralympic Winter Games. Seventy-three respondents engaged in the Emblem of Olympic Winter Games Beijing 2022 Design Competition hosted by the Beijing Organizing Committee in 2017. Thirty-seven people took part in the Online Photos and Text Collection of Ice \& Snow Season in 2016. Another 23 residents were involved in the Beijing 2022 Global Staff Recruitment in 2017.

The respondents' support for Beijing 2022 was measured by a five-point Likert scale from "strongly oppose" to "strongly support". $74.8 \%$ and $11.9 \%$ respondents indicated that they would "support" and "strongly support" Beijing 2022, respectively. Over 10.4\% of respondents hold the neutral attitude. The respondents with "strongly oppose" and "oppose" attitudes were only $0.2 \%$ and $2.8 \%$. A five-point Likert scale was also used to measure agreement of the host residents' participation in the decision-making and its implementation of Beijing 2022. The respondents with "strongly disagreed" and "strongly agreed" attitudes accounted for $1.3 \%$ and 3.3\%, respectively. Over half of respondents (52.6\%) agreed to public participation in Beijing 2022, while $7.2 \%$ of respondents disagreed with it. Meanwhile, $35.7 \%$ of respondents were neutral. The mean and standard deviation of the respondents' agreement levels among the different groups of the social and demographic variables are presented in Table 3. The results showed that males had a higher agreement level than females. In general, the older respondents agreed more than the younger ones, especially for the residents aged 51-60 with the highest mean being 3.65. Respondents with the higher education level had lower levels of agreement, e.g., the mean was the lowest, 2.67 , for respondents with master degrees. Similarly, respondents with the higher level of income had a lower level of agreement. Farmers and residents who lived in the rural area agreed more than other groups with public participation in the decision-making process and its implementation for Beijing 2022. 
Table 3. Description analysis of the respondents' agreement level of public participation in the decision-making process of Beijing 2022.

\begin{tabular}{lccc}
\hline Social and Demographic Character & Group & Mean & Standard Deviation (SD) \\
\hline Gender & Male & 3.51 & 0.762 \\
Age & Female & 3.48 & 0.708 \\
(years old) & $18-30$ & 3.40 & 0.738 \\
& $31-40$ & 3.45 & 0.673 \\
& $41-50$ & 3.56 & 0.752 \\
Education & $51-60$ & 3.65 & 0.699 \\
& Over 60 & 3.55 & 0.788 \\
& Primary school & 3.58 & 0.835 \\
& Middle school & 3.61 & 0.692 \\
Annual household & High school & 3.45 & 0.774 \\
income (10,000 RMB) & University & 3.42 & 0.689 \\
& Master & 2.67 & 0.577 \\
Profession & $1-5$ & 3.52 & 0.790 \\
& 6-10 & 3.50 & 0.645 \\
& 11-15 & 3.47 & 0.634 \\
& Over 15 & 3.26 & 0.893 \\
& Corporate employee & 3.51 & 0.616 \\
Place of & Farmer & 3.70 & 0.760 \\
residence & Self-entrepreneur & 3.34 & 0.820 \\
& Retiree & 3.54 & 0.736 \\
& Student & 3.46 & 0.762 \\
& Government staff & 3.31 & 0.763 \\
& None or other & 3.50 & 0.694 \\
& Teacher and researcher & 3.45 & 0.602 \\
& Media and NGOs staff & 3.12 & 0.704 \\
& City & 3.41 & 0.725 \\
& Rural area & 3.61 & 0.747 \\
& Suburb & 3.56 & 0.711 \\
\hline
\end{tabular}

Mann-Whitney $U$ test showed that agreement degree of the respondents was not significantly related to their sex. Kruskal-Wallis ANOVA analysis indicated that agreement of the host residents was not significantly related to the respondents' annual household income. One-way ANOVA analysis showed that agreement of the host residents was significantly related to the respondents' education level $(p=0.017<0.05)$, profession $(p=0.002<0.05)$, and place of residence $(p=0.009<0.05)$. Regarding the education level, there were significant differences of the agreement degree between master and primary school $(p=0.035<0.05)$; between middle school and college/university $(p=0.009<0.05)$, master degree $(p=0.026<0.05)$, high school $(p=0.035<0.05)$. In terms of profession of the respondents, there were significant differences of the agreement degree between farmer and government staff $(p=0.002<0.05)$, corporate employee $(p=0.034<0.05)$, self-entrepreneur $(p=0.000<0.05)$, student $(p=0.047<0.05)$, media and NGOs staff $(p=0.000<0.05)$; between government staff and media/NGOs staff $(p=0.012<0.05)$; between corporate employee and media and NGOs staff $(p=0.001<0.05)$; between teacher/researcher and media/NGOs staff $(p=0.035<0.05)$; between self-entrepreneur and media/NGOs staff $(p=0.007<0.05)$; between student and media/NGOs staff $(p=0.002<0.05)$; between retiree and media/NGOs staff $(p=0.001<0.05)$; between media/NGOs staff and no job $(p=0.002<0.05)$. Considering the living place, there was significant difference of the agreement degree between respondents from city and rural areas $(p=0.002<0.05)$.

Regarding the opinion on function of the environmental cooperation between the government and the public during the Beijing 2022 Winter Olympics, the residents had different views. Nearly $28.5 \%$ of respondents considered that the first role was helping the government to understand the public's needs, followed by providing the public with needed environmental services (18.9\% of respondents) and promoting cooperation with the relevant stakeholders $(16.1 \%)$. The fourth and fifth functions were increasing interaction between government and public $(15.5 \%)$ and promoting cross-sectoral environmental cooperation $(12.5 \%)$. The last role was reducing the administrative costs $(8.0 \%)$. 
The respondents were asked to select the basic principle of environmental public participation related to the Beijing 2022 Winter Olympics. Eight principles were mentioned. The justice and fairness principle was considered the top principle by $24.5 \%$ of the respondents, followed by open and transparent principle $(18.2 \%)$, voluntary principle $(14.9 \%)$, principle of participation by law $(12.5 \%)$, and inclusiveness principle $(8.8 \%)$. The last three principles included representativeness principle $(8.3 \%)$, convenience and accessibility principle ( $8.2 \%)$, and the principle of effectiveness and efficiency $(4.5 \%)$.

In terms of the best stage for public participation in the venue construction project, over one-fifth of respondents $(21.5 \%)$ selected public participation in the whole cycle. The planning and pre-construction preparation stage was the second option for $17.6 \%$ of the respondents, followed by the construction phase $(17.3 \%)$ and the feasibility investigation stage $(14.2 \%)$. The project proposal stage $(10.1 \%)$, project completion and check stage $(7.5 \%)$, and survey and design stage $(7.0 \%)$ were considered the least important stages. The smallest number of people (4.9\%) selected the assessment and evaluation stage.

Some scholars have noted how different participatory mechanisms constitute and produce the "public" they seek input from [71]. For example, stakeholder consultations construct a "partisan public", citizen juries construct a "pure public", and consultative panels construct an "affected public". Which indicator was used to indicate a good mechanism for public participation perceived by the residents? Openness of the participation process was thought as the first indicator by most respondents (21.3\%). Legitimacy, that is the legalization and institutionalization of public participation, was perceived as the second indicator of good mechanism by $19.3 \%$ of the respondents. The next three factors were diversification of participants (17.1\%), convenience of participation (16.9\%), and issue diversity (14.8\%), respectively. The last one had the maximum effectiveness and cost-benefit balance (10.6\%).

For the factors influencing public participation, respondents could select at most three out of ten options (Figure 3). The first option for the respondents (42.4\%) was benefits to individual and family. The last two options were awareness of the right to know and participation power $(12.5 \%)$ and influence of friends and relatives (15.6\%). The other factors had similar rates from $25.9 \%$ to $36.6 \%$, for example, legitimacy of participatory process and participation cost. Studies suggest that when it comes to hosting a mega-event, host community residents tend to place more importance on the positive social impacts such as community pride and international recognition than on the positive economic impacts an event can generate [72].

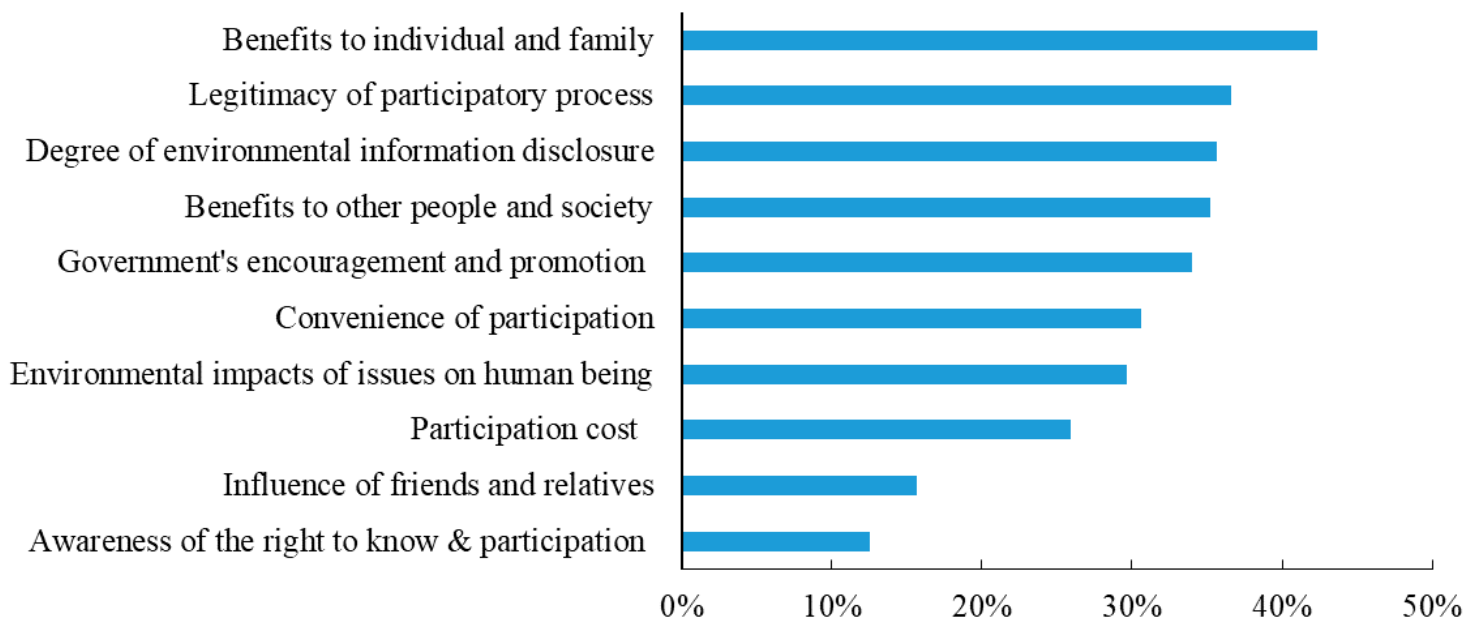

Figure 3. The factors influencing public participation in Beijing $2022(n=614)$.

To ensure public participation in the environmental decision making and management of the 2022 Winter Olympic Games, some institutional systems are necessary (Table 4). The most important system perceived by the respondents was the citizen supervision and reporting system (31.6\%). The next one was environmental right-to-know system (17.1\%). Social trust mechanism was considered the third safeguard system by $12.4 \%$. The people who selected these three systems accounted for over $60 \%$ of 
the respondents. The environmental litigation system was the least important system by only $2.3 \%$ of the respondents.

Table 4. The important safeguard systems for environmental public participation in Beijing 2022.

\begin{tabular}{lll}
\hline \multicolumn{1}{c}{ Important Ensuring System } & Number & Percent (\%) \\
\hline Citizen supervision and reporting system & 194 & 31.6 \\
Environmental right-to-know system & 105 & 17.1 \\
Social trust mechanism & 76 & 12.4 \\
Supervision system of media and public opinion & 70 & 11.4 \\
Environmental information disclosure system & 65 & 10.6 \\
Incentive system & 33 & 5.4 \\
Public complaint system & 28 & 4.6 \\
Hearing system & 27 & 4.4 \\
Environmental litigation system & 14 & 2.3 \\
\hline
\end{tabular}

\subsection{Information Transparency and Public Trust}

Opening data can be an essential measure to increase transparency and accountability, promote participation, and stimulate innovation in institutions. General knowledge of the Chinese people regarding Beijing 2022 proved high. Most of our respondents (>84\%) have been seeing, reading, or hearing something about the Beijing 2022 bid in the past three years, which was widely reported in Chinese media. Beijing 2022 is a mega-event after the 2008 Beijing Summer Olympics in China. The respondents were aware of Beijing 2022, but did not know the details of the decision-making process. More than $70 \%$ of the respondents did not know the decision-making process of joint bidding and hosting of Beijing 2022. Only $1.5 \%$ of the respondents perceived they fully knew the process.

Transparency of information has a growing potential. The issue that many governments and companies are tackling today is not whether to open their data, but how to do so. The organizers of Beijing 2022 are striving to provide stakeholders with the necessary information about the Games' preparations. For this purpose, the official website, official Wechat, and microblog have been held. Over a quarter of the respondents (26.9\%) knew the BWOOC website (https://www.beijing2022.cn/), while only $19.7 \%$ of respondents had browsed and accessed the website in last two years. In total $21.3 \%$ of respondents followed the official Wechat and microblog accounts of the BWOOC. Sixty-four (10.45\%) respondents had also accessed the IOC's website (https://www.olympic.org/).

Data accessibility, reliability, accuracy and usability, data literacy, and trust in the data that governments share are also prerequisites for data usage. For environmental information on the 2022 Beijing Olympic Games, Figure 4 showed that the respondents relied especially on TV (27.6\%), the internet $(19.9 \%)$, friends, neighbors, and relatives $(11.4 \%)$, and WeChat public account and moments $(10.1 \%)$. These four sources accounted for over $69.0 \%$ of the responses. The three least used information sources were the construction companies $(0.3 \%)$, international organizations $(0.4 \%)$, and personal videos and documentaries $(0.7 \%)$. Other relevant information providers were radio, newspapers, the local and national government, etc. Such results are a little different in our previous study on high-speed railway, the first information source is "relatives and friends" (37\%); but there is a similar finding with a study on nuclear power plants [23], e.g., TV (61\%) and the internet (13\%) are main information sources. The Mann-Whitney $U$ test showed that there was no significant difference of the information sources between male and female. Kruskal-Wallis ANOVA analysis showed that respondents' information sources of Beijing 2022 were significantly related to their age $(p=0.038<0.05)$, education level $(p=0.025<0.05)$, and profession $(p=0.046<0.05)$, but not significantly related to their annual household income and place of residence. In terms of the comparison of sample to sample, there were significant differences between the respondents over 60 years old and 18-30-year-olds $(p=0.019<0.05), 31-40$-year-olds $(p=0.026<0.05)$. There were significant differences between the respondents with master degrees and primary school degree $(p=0.011<0.05)$, middle school degree 
$(p=0.014<0.05)$. There were significant differences between the farmers and governmental staff $(p=0.009<0.05)$, teacher and researcher $(p=0.013<0.05)$.

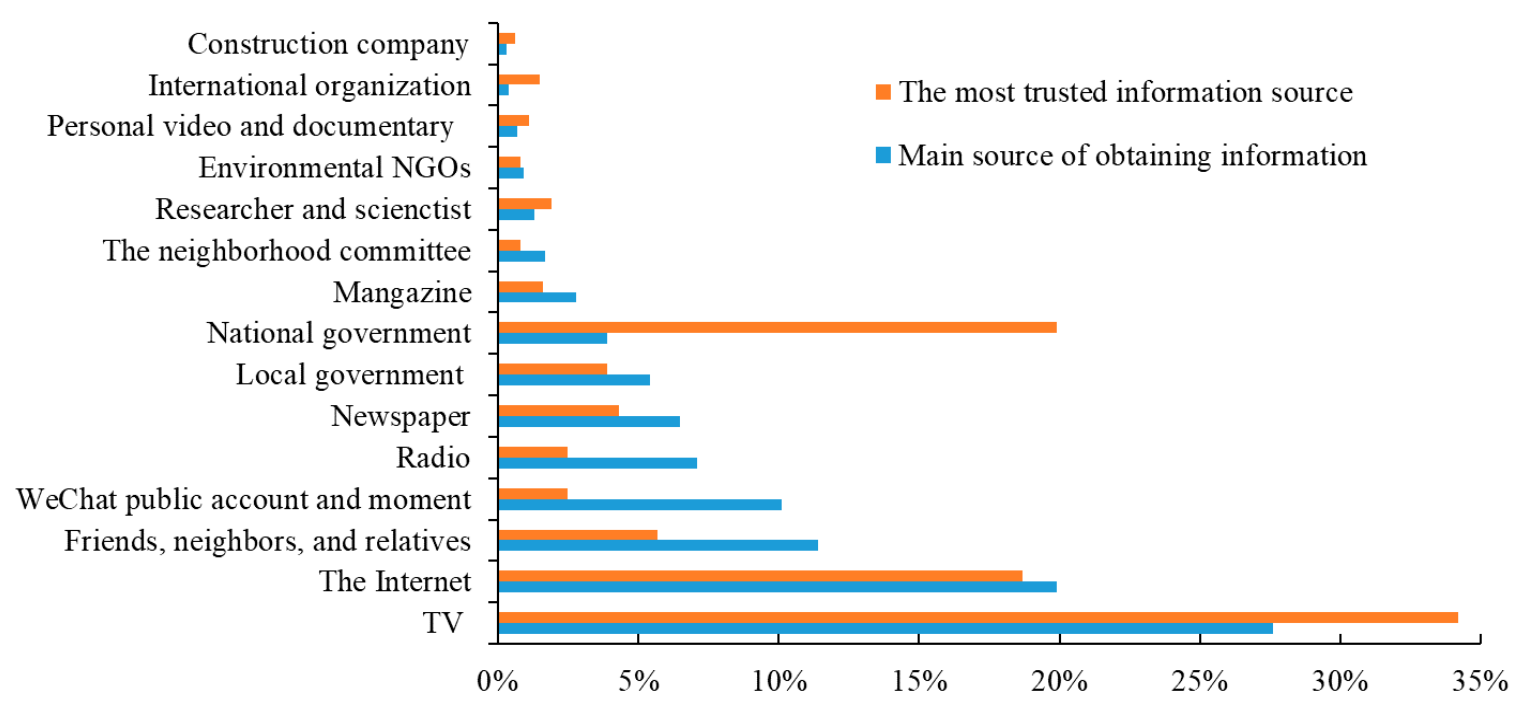

Figure 4. Information sources used and trusted on environmental issues of Beijing 2022.

In fact, access to data alone is not enough to enable civic participation. Citizens need a belief in the quality of the information, trust in government responsiveness, and prior experiences often leave citizens skeptical about their ability to create change even when equipped with data. As showed in Figure 4, TV is considered as the most trustworthy source of information $(34.2 \%)$, followed by the national government $(19.9 \%)$, and the Internet $(18.7 \%)$. Very few considered the construction company $(0.6 \%)$, the neighborhood committee $(0.8 \%)$, and the environmental NGO $(0.8 \%)$ as a trustworthy information source. This is quite different, and it contrasts similar studies on nuclear power plant and high-speed railway that the national government was the trustworthy information source [23]. Mann-Whitney $U$ test showed that there was no significant difference of the trusted sources between male and female. Kruskal-Wallis ANOVA analysis indicated that the trustworthy source was not significantly related to the respondents' profession and place of residence. There were significant relationships between the trustworthy source and the respondents' age $(p=0.019<0.05)$, education level $(p=0.033<0.05)$, and annual household income $(p=0.009<0.05)$. Regarding the comparison of sample to sample, there was significant difference between the respondents with annual household income 10-50 and 60-100 thousand RMB $(p=0.025<0.05)$.

Trust is a desirable Chinese traditional cultural value. Compared with Western societies such as the United States, Chinese societies are low-trust societies, though there is high level of trust in the government [73]. Furthermore, there is also a consistent lack of institutional constraints in China. We asked the residents about their most trustworthy facet of environmental protection and management for Beijing 2022 Winter Olympics. The coverage and efficiency of the provided environmental services was considered as the most trustworthy one by $35.1 \%$ of the respondents. About one-fourth of the respondents $(24.7 \%)$ believed the great efforts in environmental protection of governments. The next two included improvement of environmental decision-making procedure $(16.6 \%)$ and environmental information disclosure (13.9\%). Environmental professional competitiveness was ranked the last by $9.7 \%$ of respondents.

Effective communication could avoid (environmental) conflicts between different stakeholders. Beijing 2022 provides a unique communication platform that is not only recognized by sponsors but also by host cities' residents. However, only $8.6 \%$ and $6.2 \%$ of respondents considered communication between the government and public, and between construction companies of venues and public as sufficient, respectively. Over $30 \%$ of the respondents considered any communication with governmental 
agencies and companies as "useless". Almost $90 \%$ respondents experienced no communication between the key stakeholders for Beijing 2022.

\subsection{Public Opinions on E-Participation, ICTs Roles and Ranking in Beijing 2022 Environmental Public Participation}

Using ICTs, e-participation is a tool that promotes the inclusion of the public in participative and deliberative decision-making processes, thus contributing to a transformation of the interaction between government and citizens in environmental governance and sustainable development [11]. Only 7.7\% of respondents knew or had heard about the environmental e-participation concept in the past three years. According to the United Nations E-Government Survey 2016 [42], China is ranked 22nd on the e-participation index, which has moved to the Top 25 performers from the Top 50 performers in the last two years. Mann-Whitney $U$ test showed that there was no significant difference of the public knowledge of environmental e-participation between males and females. Kruskal-Wallis ANOVA analysis indicated that respondents' knowledge of the environmental e-participation concept was not significantly related to their social and demographic characteristics. Based on China's Internet Network Information Center (CNNIC) data (2019) [74], the national internet users are 829 million, which accounts for $59.6 \%$ of the Chinese population at the end of 2018. The internet users are mainly younger people between 10-39 years old (67.8\%) and 40-49 years old (15.6\%). Utilization rate of WeChat Moments, Qzone (which was developed by a Chinese Tencent Company in 2005; its function is similar to blog), and Microblog was $83.4 \%, 58.8 \%$, and $42.3 \%$ of the Chinese population at the end of 2018 , respectively. In our survey, $77.4 \%$ of respondents had used the internet in last year, which is higher than the national average level. More than $80 \%$ and nearly $78 \%$ of respondents had smartphones and computers/laptops. The public reached out to the government, academia, and society through multiple channels such as WeChat groups/Moments/the official account (70\% of respondents used), QQ (an instant messaging service similar to MSN in China, 37.6\%), Microblog/blog (23.8\%), and video websites (20.8\%) in the past two years. Less than ten percent of respondents had used the internet bulletin board system (BBS) and personal log/website.

Information generation, processing, transmission, and use become fundamental (re)sources of power and transformation in environmental governance, in which ICTs gain transformative powers. Nearly 83\% of respondents thought that, compared with the 2008 Beijing Summer Olympic Games, more and more people were participating in the dissemination of environmental information about the 2022 Winter Olympic Games through the Internet. Looking at ICTs as tools for dealing with environmental issues from a developing and emerging country perspective, the International Telecommunication Union (2008) noted six application categories: environmental observation, environmental analysis, environmental planning, environmental management and protection, impact and mitigating effects of ICT utilization, and environmental capacity building [75]. Here we are mainly concerned with the environmental management and environmental capacity building aspects. The respondents were invited to give their opinions on the roles of ICTs in the environmental management and sustainability of Beijing 2022. A five-point Likert scale from 1 (strongly disagree) to 5 (strongly agree) was applied into 19 aspects (Figure 5). Total $26.5 \%, 26.2 \%$, and $26.1 \%$ of respondents gave a "strongly agree" rating on reducing government investment and cost in environmental protection, expanding communication channels between government and public, and providing a space for public, governments, companies, and NGOs to communicate, respectively. Providing the environmental information to the public at anytime and anywhere, promoting more transparent use of environmental information, providing a space for public, governments, companies, and NGOs to communicate got an "agree" rating by $61.1 \%, 56.7 \%$, and $56.6 \%$ of respondents. In general, over $70 \%$ of respondents had positive attitudes towards all items in the survey. Only less than $1.0 \%$ and $4.9 \%$ of respondents strongly disagreed or disagreed with the aspects of the ICTs in Beijing 2022. Other residents held a neutral stance. 


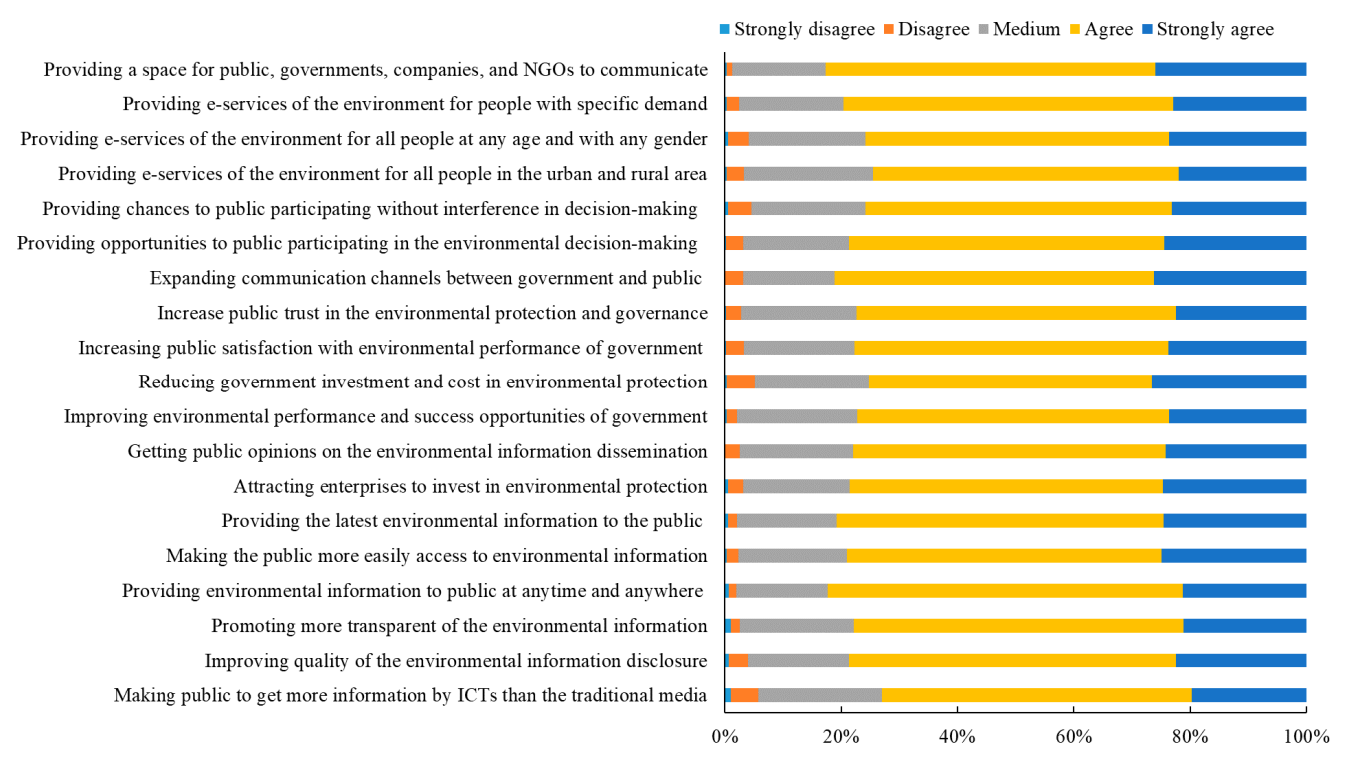

Figure 5. Public opinions on ICT roles in the environmental management and sustainability of Beijing $2022(n=614)$.

Meanwhile, most respondents $(80 \%)$ recognized that the national policy would have a major influence on the public participation in the environmental management of Beijing 2022. In addition, more than $85 \%$ of respondents were optimistic about the role of ICTs in promoting environmental public participation in 2022 Winter Olympics. Mann-Whitney U test showed that there was no significant difference of the optimistic attitude towards the role of ICTs between males and females. One-way ANOVA analysis showed that there was not a significant difference for the optimistic attitudes of ICTs roles by the respondents regarding their age, annual household income, and place of residence. Kruskal-Wallis ANOVA analysis indicated that the optimistic attitudes of ICT roles by the respondents was not significantly related to the respondents' education level and profession.

Communication is a fundamental human activity. The advancement of ICTs has helped to advance the ways in which we communicate with each other. In view of the aspects of ICTs in promoting communication among government, enterprises, and the public, nearly $25 \%$ of respondents considered "increasing communication channels" as the most important aspect, followed by "increasing possibility of policy recommendations from the public" $(17.7 \%)$, "using the required information at any time" $(15.2 \%)$, "increasing the possibility of contacting the public" (8.2\%), and "speeding up the possibility of contact" (8.2\%).

ICTs have a wide application in different levels of environmental public participation. According to our survey on Beijing 2022, ICTs can play the greatest role in national-level actions (42.5\%), followed by organization/social group level activities (18.2\%), regional action (13.4\%), community-level activities $(12.9 \%)$, individual actions (7.7\%), and international-level actions (5\%).

We asked the respondents to rank the role of different ICTs in the environmental public participation in Beijing 2022. Ten ICTs were listed here including newspapers, letters, and magazines, which are broadly communication technologies (Table 5). If the role of one ICT was ranked first, it would get 10 points. The tenth role of an ICT would get 1 point. The ranking of each role is calculated by total points (multiplying the number of respondents by role points of ICT). The average score of each ICT equals the total score over total respondents of the survey (614). The results showed that the ranking score of ICT roles ranged from 9 to 1710. Based on total score and average score, the order of different ICT roles is the TV $>$ smart phone $>$ the internet $>$ radio $>$ video $>$ newspaper $>$ community bulletin $>$ magazine $>$ fax/landline phone $>$ letter. Television got the highest score with 4693 and an average of 7.64 . However, 171 respondents (27.9\%), 152 respondents $(24.8 \%)$, and 148 respondents $(24.1 \%)$ considered the internet, TV, and smart phone to come first, respectively. Smart phone was most 
commonly selected to rank second by $21.3 \%$ of the respondents, followed by TV. Generally, letter got the lowest score with 1988 and 3.24 .

Table 5. Ranking of different ICTs' roles for promoting environmental public participation $(\mathrm{n}=614)$.

\begin{tabular}{|c|c|c|c|c|c|c|c|c|c|c|c|c|}
\hline \multirow{2}{*}{ ICTs } & \multicolumn{10}{|c|}{ Ranking Score } & \multirow{2}{*}{$\begin{array}{l}\text { Total } \\
\text { Score }\end{array}$} & \multirow{2}{*}{$\begin{array}{c}\text { Average } \\
\text { Score }\end{array}$} \\
\hline & No.1 & No.2 & No.3 & No.4 & No.5 & No.6 & No.7 & No.8 & No.9 & No.10 & & \\
\hline TV & 1520 & 1008 & 800 & 581 & 264 & 215 & 132 & 75 & 26 & 9 & 4693 & 7.64 \\
\hline Smartphone & 1480 & 1179 & 680 & 518 & 276 & 195 & 124 & 81 & 44 & 11 & 4588 & 7.47 \\
\hline The Internet & 1710 & 486 & 528 & 322 & 96 & 200 & 216 & 120 & 90 & 82 & 3850 & 6.27 \\
\hline Radio & 160 & 693 & 664 & 700 & 630 & 415 & 240 & 117 & 48 & 27 & 3694 & 6.02 \\
\hline Video & 400 & 675 & 568 & 490 & 414 & 295 & 216 & 225 & 104 & 49 & 3436 & 5.60 \\
\hline Newspaper & 220 & 378 & 576 & 490 & 684 & 515 & 276 & 180 & 64 & 29 & 3412 & 5.56 \\
\hline Community bulletin & 390 & 297 & 336 & 392 & 408 & 375 & 392 & 294 & 122 & 44 & 3050 & 4.97 \\
\hline Magazine & 50 & 225 & 272 & 315 & 510 & 440 & 356 & 309 & 130 & 75 & 2682 & 4.37 \\
\hline Fax/landline phone & 70 & 108 & 128 & 238 & 294 & 300 & 244 & 210 & 324 & 143 & 2059 & 3.35 \\
\hline Letter & 40 & 81 & 136 & 252 & 258 & 195 & 340 & 252 & 274 & 160 & 1988 & 3.24 \\
\hline
\end{tabular}

The respondents also ranked eight current specific functions of ICTs in environmental public participation in Beijing 2022 (Table 6). If one function was ranked first, it would get 8 points. The eighth function would get 1 point. Total points equaled to multiplying the number of respondents by points of function. The average score is calculated by total points over total respondents of the survey $(n=614)$. The total score changed from 2288 to 3233, and the average score was from 3.74 to 5.27. The most important function of ICTs was real-time access to information on environmental issues and sustainability of Beijing 2022. About $24 \%$ of respondents put it as the No.1 role. The order of different functions is as follows: real-time access to information $>$ release and present opinion freely $>$ communicate and reveal ideas $>$ participate in the decision-making $>$ involve online vote and survey $>$ organize the collective actions $>$ engage in the consultation. The least important function was "engage in the consultation." The average score was only 3.74 . Only $7.3 \%$ of respondents put it as the No.1 role.

No doubt, ICTs greatly influence the involved stakeholders, the process of public participation, and society. These effects were presented in different aspects, as our study showed (Figure 6). To promote transparency of the governmental decision-making was perceived as the most important impact by $17.3 \%$ of respondents. The next one was increasing the level of public participation and influence on decision-making $(16.3 \%)$. The third one was helping society to form the atmosphere of environmental protection $(11.9 \%)$. The least influence was reducing cost of organizational action and improving efficiency (6.0\%).

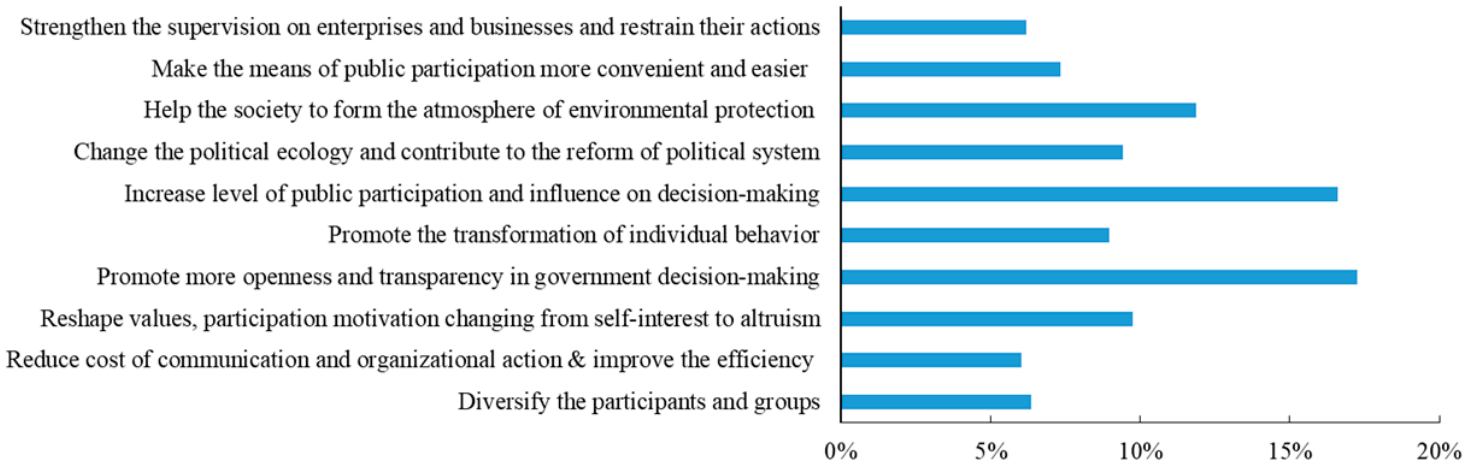

Figure 6. ICT impacts on public participation in environmental management and sustainability of Beijing $2022(\mathrm{n}=614)$. 
Table 6. Ranking the specific functions of ICTs for environmental public participation in Beijing 2022 ( $\mathrm{n}=614$ ).

\begin{tabular}{|c|c|c|c|c|c|c|c|c|c|c|}
\hline \multirow{2}{*}{ ICT Functions } & \multicolumn{8}{|c|}{ Ranking Score } & \multirow{2}{*}{$\begin{array}{l}\text { Total } \\
\text { Score }\end{array}$} & \multirow{2}{*}{$\begin{array}{c}\text { Average } \\
\text { Score }\end{array}$} \\
\hline & No.1 & No.2 & No.3 & No.4 & No.5 & No.6 & No.7 & No.8 & & \\
\hline Real-time access to information & 1160 & 707 & 498 & 325 & 220 & 159 & 104 & 60 & 3233 & 5.27 \\
\hline Release and present opinion freely & 568 & 728 & 642 & 475 & 296 & 198 & 94 & 50 & 3051 & 4.97 \\
\hline Communicate and reveal ideas & 408 & 504 & 576 & 610 & 392 & 177 & 138 & 47 & 2852 & 4.64 \\
\hline Participate in the decision-making & 1072 & 364 & 306 & 285 & 248 & 192 & 166 & 111 & 2744 & 4.47 \\
\hline Involve online vote and survey & 456 & 644 & 438 & 360 & 372 & 240 & 154 & 70 & 2734 & 4.45 \\
\hline $\begin{array}{l}\text { Participate without limitation of } \\
\text { time and place }\end{array}$ & 496 & 490 & 498 & 430 & 308 & 243 & 156 & 77 & 2698 & 4.39 \\
\hline Organize the collective actions & 392 & 469 & 396 & 345 & 336 & 291 & 166 & 99 & 2494 & 4.06 \\
\hline Engage in the consultation & 360 & 392 & 330 & 240 & 284 & 342 & 250 & 100 & 2298 & 3.74 \\
\hline
\end{tabular}

\section{Discussion and Implication}

\subsection{Discussion}

Access to information and public participation are two pillars of the Aarhus Convention that emphasize the role and importance of information disclosure and public participation in environmental decision-making. The sustainability of mega sporting events, including Beijing 2022, depends on the extent to which the host community views are incorporated into the planning and decision-making process. In China, a traditional top-down decision-making approach to policy and projects, which lacks public participation and sufficient information openness, still prevails [22]. However, the Chinese government has been trying to enhance the role of public participation in its decision-making in the last decade. We want to answer three key questions by investigating the host residents of the Beijing 2022. Our study showed that a very low level of public participation in practice (less than $10 \%$ host respondents) but a higher degree of willingness to participate (nearly $56 \%$ respondents strongly agreed and agreed) in Beijing 2022. The support degree for the bid and hosting of Beijing 2022 was very high with over $85 \%$ of the respondents supporting it. Such results are in line with our studies on a high-speed railway construction project, for example, only $18 \%$ of the respondents participated in the environmental impact assessment (EIA) of the Beijing-Shanghai high-speed railway [76]. Through the implementation of the EIA survey of the Haiyang nuclear power plant project, only $18 \%$ of the respondents had gained knowledge about the EIA and 12\% of them participated in it [23]. Regarding the Olympic Games, Kokolakakis et al. (2019) analyzed the short-term sports participation legacy of the London 2012 Olympic and Paralympic Games on the adult population in England. The results demonstrate a positive association with participation from hosting the Games [77]. The residents' opinions on function, principle, stage, good mechanism for public participation are discussed in our study. For the factors influencing public participation, benefits to individual and family was selected as the first option (42.4\%). Studies clearly suggest that inputs from all stakeholders, including residents and grassroots organizations, should be solicited and opportunities for their involvement in the bidding and planning process should be provided [78]. Such involvement should happen at the very early stages of the bidding process and should continue throughout the development process. Our study also confirms this finding. We confirm the results of other studies that residents' participation leads to higher support and is critical for the events' success and long-term economic viability [79].

Regarding the second question, "what are the main information sources and roles of the ICTs played in the environmental management and sustainability of Beijing 2022?", TV and the internet were the two main information sources and the respondents hold the very positive attitudes towards the ICT roles in the environmental public participation in Beijing 2022. Such results are a little different from our previous study on the information sources of the public protests against the Beijing-Shenyang high-speed railway in China [22]. For information on the environmental impacts of the Beijing-Shenyang high-speed railway, the public relied significantly on relatives and friends (37\%), the internet $(21 \%)$, television programs $(18 \%)$, and newspapers $(15 \%)$. However, our results here are similar to our previous study on public participation and trust in a nuclear power plant [23]. Citizens around Haiyang obtain general information on nuclear power mainly from the media (78\%)—especially 
TV $(61 \%)$ and the internet (13\%)-and to a lesser extent directly from scientific institutions (11.5\%) and from relatives and friends (6\%). Just like other political issues, the news media functioned as a conduit for information of bidding and hosting the Olympic Games, through which the citizens obtained the relevant information. A Lu et al. study conducted in both China with 505 respondents and the US with 449 respondents shows the causal relationship between media content and resident attitude change on Beijing and Boston bidding for the Olympic Games [80]. As Shaw (2008) argued about the 2010 Vancouver Olympics, had Vancouver based journalists done a solid exposé of the Salt Lake Winter Olympics and provided this information during their pre-plebiscite period, Vancouverites could have made a far more informed choice [81]. Filo et al. analyzed the existing body of knowledge of social media in the field of sport management from a service-dominant logic perspective. Three categories of social media research were identified: strategic, operational, and user-focused [82]. Our research belongs to the joint first and third one. Though we highlight the ICT roles in public participation, the key lesson from the review is that the rise of ICT tools will not do away with the politics of participation in urban water governance, and the higher forms of authoritative and deliberative participation can only be possible given the political will to implement these [54]. Many of the Chinese internet users are to an extent aware that information is censored and filtered by the government. This may differ, however, between rural and urban areas. Chinese citizens in Beijing who took part in a recent survey see much value in ICT tools (including social media) to enhance public participation in the domain of environmental sustainability; at the same time, they are conscious that so far its influence on decision-making processes has been limited [11]. We echo Fung et al. (2013:37) who claimed that "the failure to realize e-democracy is not in the first instance a technological problem, but a political one. Solutions, for those desiring greater direct e-democracy, require political innovations much more than technological ones" [83]. ICT tools may also help in understanding social and political realities, for example, through collecting public opinion, public narratives, and lived experiences of citizens, and playing a broader role than just enabling or hindering public participation.

For the third research question "which are main factors affecting the host residents' attitude and knowledge of public participation?", our results summarized in Table 7 indicate the relationship between the host residents' participation, information access, and their demographic characters. The findings show the education level is the first affecting factor, followed by profession, annual income and age, and place of residence. Sex has no impact at all. There are many studies on the between residents' perceptions, their perceived impacts, their support for mega sporting events and different impact factors. Support for the 2014 Winter Olympics in Sochi tended to be strongest among non-Russians, the younger generation, and residents who have good knowledge of the preparations [18]. The findings of Gursoy et al. (2017) indicate that three factors including trust, community attachment, and community concern are likely to influence residents' perception of the impacts of hosting a mega event in their community [84]. Findings indicate that environmentally conscious residents do not support the 2002 Winter Olympics, while those who are economically dependent on tourism and those who participate in outdoor activities generally support the Olympics [19]. However, community attachment of residents did not influence perceived Olympic opportunities or support for the Olympics. Some experts have analyzed the barriers and factors of effective public participation in China's environmental management. The factors include public attitudes toward environmental issues, perceived interests, direct economic benefits, public perception of the environmental, economic, and social risks, general knowledge about the issue and the project, environmental costs, and trust in the government and related corporations [22-24]. One of the greatest obstacles to overcome these factors is the public's low level of public access to relevant information and decision making [76]. 
Table 7. Summary of affecting factors in the Beijing 2022 Winter Olympics.

\begin{tabular}{lcccccc}
\hline \multicolumn{1}{c}{ Variables } & Sex & Age & Education & Annual Income & Profession & Place of Residence \\
\hline Participate in activity & 0.432 & 0.281 & $0.029^{*}$ & $0.000^{*}$ & $0.026^{*}$ & 0.609 \\
Agree to participation & 0.806 & 0.051 & $0.017^{*}$ & 0.283 & $0.002^{*}$ & $0.009^{*}$ \\
Information source & 0.564 & $0.038^{*}$ & $0.025^{*}$ & 0.479 & $0.046^{*}$ & 0.589 \\
Trustful source & 0.488 & $0.019 *$ & $0.033 *$ & $0.009 *$ & 0.110 & 0.534 \\
Knowledge of e-participation & 0.306 & 0.291 & 0.387 & 0.778 & 0.450 & 0.912 \\
Optimistic for ICT role & 0.614 & 0.114 & 0.449 & 0.859 & 0.803 & 0.226 \\
\hline
\end{tabular}

\subsection{Implication}

The current study provides initial evidence that local people especially want to participate in the Beijing 2022. This gives impetus for a novel approach to examine whether and how the whole decision-making chain could be reconfigured to provide more room for public influence. This study contributes to the burgeoning literature surrounding the Olympic Games by providing an in-depth analysis of public participation in preparation stage. In the future, this may be tracked through the development of a framework and set of indicators, and its effects reported in the 2022 Winter Olympic Games impact report on all stages from bid to post-event stage. The research also presented in this paper has implications for the development of practices and policy in a broader context that goes beyond the traditional network.

The findings offer important practical implications for the Games' various stakeholders. Information should be provided to Beijing and Zhangjiakou residents in the form of leaflets, or a website designed specifically for residents with news, discussion forums, and updates. The current website (https://www.beijing2022.cn/) is informative of governmental activities and does not explicitly address the social needs and concerns of residents. Media coverage is important in shaping residents' attitude. In addition, event organizers should reduce barriers to participation in the Games and include marginalized communities. To achieve environmental and socio-cultural sustainability, local community empowerment, involvement, and participation are crucial. Residents should be informed of the potential long-term economic and environmental benefits (such as new infrastructure and facilities) prior to the Games. Such measures are likely to foster positive attitudes and increase support for the 2022 Olympic Games among local residents. In addition, it is important for event organizers to communicate the likely impacts to non-host cities. The Beijing Winter Olympic Organizing Committee has been working with a range of partners from the public, private, and voluntary sectors covering the thematic areas of snow sports, tourism, business and marketing, volunteering, and transport. The official website keeps its residents and other stakeholders informed about the latest developments. Indeed, Deccio and Baloglu (2002) note that to ensure the sustainability and success of mega events is maximized, it is important not to neglect the expectations and perceptions of the non-host community [19].

Heavy involvement of all stakeholders is likely to make the process more transparent and ease the concerns various stakeholders may have about hosting the Beijing 2022 in their community. The participation of all stakeholders in the process can provide opportunities for planners and organizers to emphasize the benefits of hosting the event for the community while addressing various stakeholders concerns directly. Developers and planners can develop internal communication strategies to change the opinion of residents who feel that they have little to gain from hosting the Beijing 2022 event in their community by promoting the benefits the event can generate for the community on one-to-one and face-to-face bases. However, this process requires the planners and organizers to invest time in listening to the concerns of the stakeholders and work with the community members to develop action plans to ease those concerns. If used effectively, collaboration can be a great tool in resolving conflicts and advancing shared visions. However, accomplishing these strategies requires the abandonment of the traditional approach in favor of a more democratic approach, which may significantly increase residents' trust in the organizing committee and the government. 
ICTs are a necessity in achieving high levels of sustainability, but ICT tools alone are not sufficient to trigger change towards participatory governance. In any case, experimentation with designs for inclusive environmental governance with ICT tools would provide important insights into understanding "digital participation" in environmental governance in the future. Adopting ICT solutions that are tailored to specific networks could make stakeholders access to information and participate in collective action. These can help to raise awareness of environmental protection and empower people with new tools. New ICTs can help public sector institutions improve the quality of their decision-making processes and of public services. In this regard, more in-depth place-based case studies are needed with a focus on how institutional and socio-political factors mediate the relationship between ICT and public participation in environmental governance.

\section{Conclusions}

Using a self-administered questionnaire, this paper profiles the environmental public participation, information access, and ICT application in the preparation stage of the Beijing 2022. We surveyed 614 host residents in Beijing and Zhangjiakou via face-to-face interviews. The findings indicated that the participation level of host respondents was low in the environmental affairs of the Beijing 2022 Winter Olympics. The respondents' views on important issues of public participation varied obviously including the participating level, principles, stages, ways, mechanism, and influencing factor. More than two-thirds of the respondents had positive attitudes towards ICTs roles and functions in Beijing 2022. ICTs have helped the public to obtain information about environmental management and sustainability issues, and to facilitate public awareness and collective action by building new management practices. Given its past as a so-called information-poor and authoritarian country, China has advanced the actual amount of environmental information disclosed to civil society actors, the diversification and pluralism of environmental information suppliers and users, and the diversification in the methods of transparency and disclosure [59]. This has significantly changed environmental governance in China. The organizers of Beijing 2022 are striving to provide stakeholders with the necessary information about the Games' preparations. Multiple approaches and tools can be used to increase open government data usage. Key issues for emerging and developing countries to research include access to data and how the masses of data collected can be brought together to provide a holistic picture of an eco-system or environment (i.e., who owns the data, who can use it, and what it can be used for).

ICTs are all but ubiquitous and the potential uses and impacts of ICTs on the Beijing 2022 are varied. While ICTs are nowadays widely used by many industries, we still only have a limited understanding of its roles and impact through a social capital lens. What must be done to ensure the usefulness and usability of this technology? How can such resources be made approachable for people who are intimidated by computer technology, for people who cannot type, for people who are disadvantaged in one way or another? How can we minimize the chance that these resources will widen the gap between haves and have-nots? Between better educated and less well educated people? Between people who are well-connected to computer resources and people who are not? However, it may be an indication of what may follow in the future.

The study is subject to several limitations and needs further research. Firstly, by taking a social survey approach for the host residents, our results cannot be easily generalized and are to be viewed within a host city context. More research with different geographical foci covering non-host communities is needed to develop a broader, and more generalizable, understanding of the role of ICTs in the Beijing 2022 operations. Secondly, the study used cross-sectional data from one period for investigation. Ideally, in order to get a clear picture on the variation in perceptions and public participation, it is necessary to collect data in several waves, including the before, during, and after the Olympics, from a panel of residents. In future, data will be collected two years before the Olympics, during the event, and two years after its occurrence, when costs and benefits can be fully assessed by residents. 
The coexistence of encouragement and constraint, confrontation and cooperation, surveillance and transparency feature in the coevolving state-society relationship in China's environmental governance. This study shows a small part of the large picture of host residents' participation in the 2022 Winter Olympics. Additional research is necessary in developing a framework and a set of indicators that can be used to measure the impact of public participation. Further policy research in relation to the sustainability of Winter Olympics is required. The host cities need to embrace the social and environmental components of sustainability, applying fully integrated sustainability principles and practices in all stages of the Olympic Games. Finally, an important subject of digital participation is the ability of citizens to utilize ICT tools and have appropriate connection and equipment in order to participate in environmental governance. With more emphasis on digitalization in urban environmental governance, a potential "digital divide" between the rich and the poor requires more attention from scholars and policymakers alike. It remains important to ask the question of who are the winners and losers of digitalization, and whether ICT tools serve the preservation of the status quo of power relations or could be used to empower the marginalized groups of society.

Supplementary Materials: The following is available online at http://www.mdpi.com/2071-1050/12/18/7712/ s1, questionnaire.

Author Contributions: G.H. took the main role in the design and execution of the survey, formal analysis, and writing-Original draft preparation; writing - Review and editing, G.Y. and Y.B. All authors have read and agreed to the published version of the manuscript.

Funding: This research was funded by The National Natural Science Foundation of China, grant number 41877529, The National Key R \& D Program of China, grant number 2019YFC0507501, and Key R \& D Project of Qinghai Province, grant number 2018-0204-SFC-0001. The APC was funded by The National Natural Science Foundation of China.

Conflicts of Interest: The authors declare no conflict of interest.

\section{References}

1. Essex, S.; Chalkley, B. Mega-sporting events in urban and regional policy: A history of the Winter Olympics. Plann. Perspect. 2004, 19, 201-204. [CrossRef]

2. Trubina, E. Mega-events in the context of capitalist modernity: The case of 2014 Sochi Winter Olympics. Eurasian Geogr. Econ. 2014, 55, 610-627. [CrossRef]

3. Holden, M.; MacKenzie, J.; Van Wynsberghe, R. Vancouver's promise of the world's first sustainable Olympic Games. Environ. Plan. C Gov. Policy 2008, 26, 882-905. [CrossRef]

4. Mol, A.P.J. Sustainability as global attractor: The greening of the 2008 Beijing Olympics. Glob. Netw. 2010, 10, 510-528. [CrossRef]

5. Cantelon, H.; Letters, M. The making of the IOC environmental policy as the third dimension of the Olympic movement. Int. Rev. Sociol. Sport 2000, 35, 294-308. [CrossRef]

6. International Olympic Committee. Olympic Agenda 2020: 20+20 Recommendations; IOC: Lausanne, Switzerland, 2014.

7. International Olympic Committee. IOC Sustainability Strategy. 2017. Available online: https://www. connect4climate.org/article/international-olympic-committee-ioc-sustainability-strategy-sport4climate (accessed on 28 July 2020).

8. Xu, L.J; Zhao, J. Research on the construction of a smart city in Zhangjiakou. J. Zhangjiakou Vocat. Tech. Col. 2017, 30, 16-19. (In Chinese)

9. Organization for Economic Co-Operation and Development. Innovative Citizen Participation and New Democratic Institutions; OECD Publications: Paris, France, 2020.

10. Beijing Winter Olympics Organizing Committee. Beijing 2022 Winter Olympic Games and Paralympic Games Bidding Report; BWOOC: Beijing, China, 2015; Volume 1.

11. He, G.Z.; Boas, I.; Mol, A.P.J.; Lu, Y.L. E-participation for Environmental Sustainability in Transitional Urban China. Sustain. Sci. 2017, 12, 187-202. [CrossRef]

12. Mol, A.P.J. Environmental governance in the information age: The emergence of informational governance. Environ. Plan. C Gov. Policy 2006, 24, 497-514. [CrossRef] 
13. Konstantaki, M.; Wickens, E. Residents' perceptions of environmental and security issues at the 2012 London Olympic Games. J. Sport Tour. 2010, 15, 337-357. [CrossRef]

14. Aitken, C.E.; Richie, J.R.B. Olympulse I: A survey of resident views concerning the XV Olympic Winter Games in Calgary. Crit. Rev. Immunol. 1983, 17, 77-88.

15. Hiller, H.H.; Wanner, R.A. Public opinion in host Olympic cities: The case of the 2010 Vancouver Winter Games. Sociology 2011, 45, 883-899. [CrossRef]

16. Ritchie, J.R.B.; Lyons, M.M. Olympulse VI: A post-event assessment of resident reaction to the XV Olympic Winter Games. J. Trav. Res. 1990, 28, 14-23. [CrossRef]

17. Karadakis, K.; Kaplanidou, K. Legacy perceptions among host and non-host Olympic Games residents: A longitudinal study of the 2010 Vancouver Olympic Games. Eur. Sport Manag. Q. 2012, 12, 243-264. [CrossRef]

18. Müller, M. Popular perception of urban transformation through megaevents: Understanding support for the 2014 Winter Olympics in Sochi. Environ. Plan. C Gov. Policy 2012, 30, 693-711. [CrossRef]

19. Deccio, C.; Baloglu, S. Nonhost community resident reactions to the 2002 Winter Olympics, the spillover impacts. J. Trav. Res. 2002, 41, 46-56. [CrossRef]

20. Jin, L.Y.; Zhang, J.J.; Ma, X.D.; Connaughton, D.P. Residents' perceptions of environmental impacts of the 2008 Beijing Green Olympic Games. Eur. Sport Manag. Q. 2011, 11, 275-300. [CrossRef]

21. United Nations. Convention on Access to Information, Public Participation in Decision-Making and Access to Justice in Environmental Matters, Aarhus, Denmark, 25 June 1998; UN Treaty Series 2161; United Nations: New York, NY, USA, 1998; p. 447.

22. He, G.Z.; Mol, A.P.J.; Lu, Y.L. Public protests against the Beijing-Shenyang high-speed railway in China. Transport. Res. D Transport. Environ. 2016, 43, 1-16. [CrossRef]

23. He, G.Z.; Mol, A.P.J.; Zhang, L.; Lu, Y.L. Public participation and trust in nuclear power development in China. Renew. Sustain. Ener. Rev. 2013, 23,1-11. [CrossRef]

24. He, G.Z.; Boasc, I.; Mol, A.P.J.; Lu, Y.L. What drives public acceptance of chemical industrial park policy and project in China? Resour. Conserv. Recycl. 2018, 138, 1-12. [CrossRef]

25. Lawrence, D.P. Environmental Impact Assessment Practical Solutions to Recurrent Problems; John Wiley \& Sons: Hoboken, NJ, USA, 2003.

26. Carpenter, J.; Brownill, S. Approaches to democratic involvement: Widening community engagement in the English Planning System. Plan. Theory Pract. 2008, 9, 227-248. [CrossRef]

27. Holder, J. Environmental Assessment the Regulation of Decision-Making; Oxford University Press: Oxford, UK, 2004.

28. Healey, P. Collaborative Planning: Shaping Places in Fragmented Societies; Macmillan: Basingstoke, UK, 2006.

29. Aizawa, K.; Wu, J.; Inoue, Y.; Sato, M. Long-term impact of the Tokyo 1964 Olympic games on sport participation: A cohort analysis. Sport Manag. Rev. 2018, 21, 86-97. [CrossRef]

30. Glucker, A.N.; Driessen, P.P.J.; Kolhoff, A.; Runhaar, H.A.C. Public participation in environmental impact assessment: Why, who and how? Environ. Impact Assess. Rev. 2013, 43, 104-111. [CrossRef]

31. Li, W.; Liu, J.; Li, D. Getting their voices heard: Three cases of public participation in environmental protection in China. J. Environ. Manag. 2012, 98, 65-72. [CrossRef]

32. Arvai, J.L. Using risk communication to disclose the outcome of a participatory decision-making process: Effects on the perceived acceptability of risk-policy decisions. Risk Anal. Int. J. 2003, 23, 281-289. [CrossRef]

33. Perlaviciute, G.; Squintani, L. Public participation in climate policy making: Toward reconciling public preferences and legal frameworks. One Earth 2020, 2, 341-348. [CrossRef]

34. Mercer-Mapstone, L.; Rifkin, W.; Louis, W.; Moffat, K. Power, participation, and exclusion through dialogue in the extractive industries: Who gets a seat at the table? Resour. Policy 2019, 61, 190-199. [CrossRef]

35. Cashmore, M. The role of science in environmental impact assessment: Process and procedure versus purpose in the development of theory. Environ. Impact Assess. Rev. 2004, 24, 403-426. [CrossRef]

36. Bartlett, R.; Kurian, P. The theory of environmental impact assessment: Implicit models of policy making. Policy Polit. 1999, 27, 415-433. [CrossRef]

37. Richardson, T. Environmental assessment and planning theory: Four short stories about power, multiple rationality, and ethics. Environ. Impact Assess. Rev. 2005, 25, 341-365. [CrossRef]

38. Webler, T.; Tuler, S.; Krueger, R. What is a good public participation process? Five perspectives from the public. Environ. Manag. 2001, 27, 435-450. 
39. Pereira, G.S.; De Conto, S.M. Public participation in Environmental Impact Assessment (EIA) and major sports events: A comparative analysis of the London 2012 Olympic Games and the Rio 2007 Pan American Games. Rev. Rosa Ventos Tur. Hospit. 2014, 6, 488-507.

40. Sharma, G. E-Government, E-Participation and challenging issues: A case study. Int. J. Comput. Internet Manag. 2014, 22, 23-35.

41. Organization for Economic Co-Operation and Development. Open Government Data: Digital Government. OECD Publishing. 2017. Available online: http://www.oecd.org/gov/digital-government/open-governmentdata.htm (accessed on 28 July 2020).

42. UN Department of Economic and Social Affairs (UNDESA). United Nations E-Government Survey 2016: E-Government in Support of Sustainable Development; ST/ESA/PAD/SER.E/205; United Nations: New York, NY, USA, 2016.

43. Berkhout, F.; Hertin, J. Impacts of Information and Communication Technologies on Environmental Sustainability, Report to the OECD; University of Sussex: Brighton, UK, 2001.

44. Bojovic, D.; Bonzanigo, L.; Giupponi, C.; Maziotis, A. Online participation in climate change adaptation. J. Environ. Manag. 2015, 157, 8-19. [CrossRef]

45. Barrios-O'Neill, D.; Schuitema, G. Online engagement for sustainable energy projects: A systematic review and framework for integration. Renew. Sustain. Energy Rev. 2016, 54, 1611-1621. [CrossRef]

46. Higgs, G.; Berry, R.; Kidner, D.; Langford, M. Using IT approaches to promote public participation in renewable energy planning: Prospects and challenges. Land Use Policy 2008, 25, 596-607. [CrossRef]

47. Gramberger, M. Citizens as Partners: OECD Handbook on Information, Consultation and Public Participation in Policy-Making, Governance; OECD: Paris, France, 2001.

48. Vicente, M.R.; Novo, A. An empirical analysis of e-participation. The role of social networks and e-government over citizens' online engagement. Gov. Inf. Q. 2014, 31, 379-387. [CrossRef]

49. Medaglia, R. eParticipation Research: A Longitudinal Overview. In Electronic Participation, Proceedings of the Third IFIP WG 8.5 International Conference, ePart 2011, Delft, The Netherlands, 29 August-1 September 2011; LNCS 6847; Tambouris, E., Macintosh, A., de Bruijn, H., Eds.; Springer: Berlin/Heidelberg, Germany, 2011; pp. 99-108.

50. Wagner, S.A.; Vogt, S.; Kabst, R. How IT and social change facilitates public participation: A stakeholderoriented approach. Gov. Inf. Q. 2016, 33, 435-443. [CrossRef]

51. Wagner, S.A.; Vogt, S.; Kabst, R. The future of public participation: Empirical analysis from the viewpoint of policy-makers. Technol. Forecast. Soc. Chang. 2016, 106, 65-73. [CrossRef]

52. Bertot, J.C.; Jaeger, P.T.; Hansen, D. The impact of polices on government social media usage: Issues, challenges, and recommendations. Gov. Inf. Q. 2012, 29, 30-40. [CrossRef]

53. Sieber, R.E. Public participation geographic information systems across borders. Can. Geogr. 2010, 47, 50-61. [CrossRef]

54. Mukhtarov, F.; Dieperink, C.; Driessen, P. The influence of information and communication technologies on public participation in urban water governance: A review of place-based research. Environ. Sci. Policy 2018, 89, 430-438. [CrossRef]

55. Evans-Cowley, J.; Hollander, J. The new generation of public participation: Internet-based participation tools. Plann. Pract. Res. 2010, 25, 397-408. [CrossRef]

56. Vogt, S.; Förster, B.; Kabst, R. Social Media and e-participation. Int. J. Public Adm. Digit. Age 2014, 1, 85-105. [CrossRef]

57. Preuss, H.; Seguin, B.; O'reilly, N. Profiling major sport event visitors: The 2002 Commonwealth Games. J. Sport Tour. 2007, 12, 5-23. [CrossRef]

58. Ristea, A.; Andresen, M.A.; Leitner, M. Using tweets to understand changes in the spatial crime distribution for hockey events in Vancouver. Can. Geogr. 2018, 62, 338-351. [CrossRef]

59. Zhang, L.; Mol, A.P.J.; He, G.Z. Transparency and information disclosure in China's environmental governance. Curr. Opin. Environ. Sustain. 2016, 18, 17-24. [CrossRef]

60. Tan, Y. Transparency without democracy: The unexpected effects of China's environmental disclosure policy. Gov. Int. J. Policy Admin. Inst. 2014, 27, 37-62. [CrossRef]

61. Hsu, A.; Weinfurter, A.; Tong, J.; Xie, Y. Black and Smelly Waters: How citizen-generated transparency is addressing gaps in China's environmental management. J. Environ. Policy Plan. 2020, 1, 138-153. [CrossRef] 
62. Yang, K.C.C. The aborted Green dam-youth escort censor-ware project in China: A case study of emerging civic participation in China's internet policy-making process. Telemat. Inform. 2011, 28, 101-111. [CrossRef]

63. Zeng, J.; Chan, C.H.; Fu, K.W. How social media construct "truth" around crisis events: Weibo's rumor management strategies after the 2015 Tianjin blasts. Policy Internet 2017, 9, 297-320. [CrossRef]

64. Lu, Y.; Zhou, Q.; Hou, Q.M.; Li, B. 3D GIS application on Winter Olympics planning: A case study of Yanqing zone of 2022 Winter Olympics. Bull. Survey Mapp. 2019, 10, 133-137. (In Chinese)

65. Cheng, Z.Y.; Chen, D.Q.; Gao, D.F.; Cao, W.D.; Lu, P.F. Application of Internet plus smart site in Beijing Winter Olympic venues project. Green Build. 2019, 11, 16-19. (In Chinese)

66. Ap, J. Residents' perceptions on tourism impacts. Ann. Tour. Res. 1992, 19, 665-690. [CrossRef]

67. Gordon, R.; Brunson, M.W.; Shindler, B. Acceptance, acceptability, and trust for sagebrush restoration options in the Great Basin: A longitudinal perspective. Rangel. Ecol. Manag. 2014, 67, 573-583. [CrossRef]

68. Gaskell, G.; Bauer, M.W.; Durant, J.; Allum, N.C. Worlds apart? The reception of Genetically Modified Foods in Europe and the U.S. Science 1999, 285, 384-387. [CrossRef]

69. Mann, H.B.; Whitney, D.R. On a test of whether one of two random variables is stochastically larger than the other. Ann. Math. Stat. 1947, 18, 50-60. [CrossRef]

70. Macfarland, T.W.; Yates, J.M. Kruskal-Wallis H-Test for Oneway Analysis of Variance (ANOVA) by Ranks. In Introduction to Nonparametric Statistics for the Biological Sciences Using R; Springer International Publishing: Berlin/Heidelberg, Germany, 2016.

71. Braun, K.; Schultz, S. “. . a certain amount of engineering involved": Constructing the public in participatory governance arrangements. Public Underst. Sci. 2010, 19, 403-419. [CrossRef]

72. Gursoy, D.; Chi, C.G.; Ai, J.; Chen, B.T. Temporal change in resident perceptions of a Mega-event: The Beijing 2008 Olympic Games. Tour. Geogr. 2011, 13, 299-324. [CrossRef]

73. He, G.Z.; Mol, A.P.J.; Lu, Y.L. Trust and credibility in governing China's risk society. Environ. Sci. Technol. 2012, 46, 7442-7443. [CrossRef]

74. China's Internet Network Information Center. The 43rd Statistical Report on Internet Development in China; CNNIC: Beijing, China, 2019.

75. International Telecommunication Union. ICTs for e-Environment: Guidelines for Developing Countries, with a Focus on Climate Change; ITU: Geneva, Switzerland, 2008.

76. He, G.Z.; Mol, A.P.J.; Zhang, L.; Lu, Y.L. Environmental risks of high-speed railway in China: Public participation, perception and trust. Environ. Dev. 2015, 14,37-52. [CrossRef]

77. Kokolakakis, T.; Lera-López, F.; Ramchandani, G. Did London 2012 deliver a sports participation legacy? Sport Manag. Rev. 2019, 22, 276-287. [CrossRef]

78. Gursoy, D.; Kendall, K.W. Hosting mega events: Modelling locals' support. Ann. Tour. Res. 2006, 33, 603-623. [CrossRef]

79. Zhou, Y.; Ap, R. Residents' perceptions towards the impacts of the Beijing 2008 Olympic Games. J. Trav. Res. 2009, 48, 78-91. [CrossRef]

80. Lu, Q.L.; Mihalik, B.J.; Heere, B.; Meng, F.; Fairchild, A. Media effect on resident attitudes toward an Olympic bid. Tour. Manag. Perspect. 2019, 29, 66-75. [CrossRef]

81. Shaw, C.A. Five Ring Circus: Myths and Realities of the Olympic Games; New Society Publishers: Gabriola Island, BC, Canada, 2008.

82. Filo, K.; Lock, D.; Karg, A. Sport and social media research: A review. Sport Manag. Rev. 2015, 18, $166-181$. [CrossRef]

83. Fung, A.; Gilman, H.R.; Shkabatur, J. Six models for the internet + politics. Int. Stud. Rev. 2013, $15,30-47$. [CrossRef]

84. Gursoy, D.; Milito, M.C.; Nunkoo, R. Residents' support for a mega-event: The case of the 2014 FIFA World Cup, Natal, Brazil. J. Destin. Mark. Manag. 2017, 6, 344-352. [CrossRef]

(C) 2020 by the authors. Licensee MDPI, Basel, Switzerland. This article is an open access article distributed under the terms and conditions of the Creative Commons Attribution (CC BY) license (http://creativecommons.org/licenses/by/4.0/). 